\title{
An examination of the Devonian fishes of Michigan
}

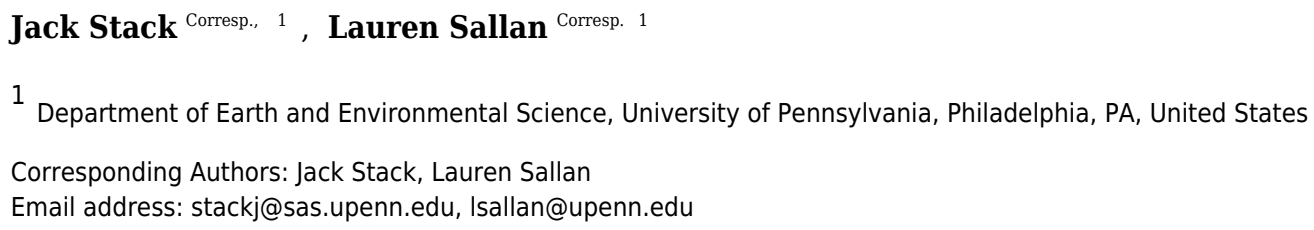

We surveyed the taxa, ecosystems, and localities of the Devonian fishes of Michigan to provide a framework for renewed study, to learn about the diversity and number of these fishes, and to investigate their connection to other North American faunas. Nineteen genera of fishes have been found in the Middle and Late Devonian deposits of Michigan, of which thirteen are 'placoderms' represented by material ranging from articulated head shields to ichthyoliths. As expected from the marine nature of these deposits, 'placoderms' are overwhelmingly arthrodire in nature, but two genera of ptyctodonts have been reported along with less common petalichthyid material. The remaining fish fauna consists of fin-spines attributed to 'acanthodians', two genera of potential crown chondrichthyans, an isolated dipnoan, and onychodont teeth/jaw material. There was an apparent drop in fish diversity and fossil abundance between Middle and Late Devonian sediments. This pattern may be attributed to a paucity of Late Devonian sites, along with a relative lack of recent collection efforts at existing outcrops. It may also be due to a shift towards open water pelagic environments at Late Devonian localities, as opposed to the nearshore reef fauna preserved in the more numerous Middle Devonian localities. The Middle Devonian vertebrate fauna in Michigan shows strong connections with same-age assemblages from Ohio and New York. Finally, we document the presence of partially articulated vertebrate remains associated with benthic invertebrates, an uncommon occurrence in Devonian strata outside of North America. We anticipate this new survey will guide future field work efforts in an undersampled yet highly accessible region that preserves an abundance of fishes from a critical interval in marine vertebrate evolution. 


\section{An Examination of the Devonian Fishes of Michigan}

2 Jack Stack ${ }^{1}$ and Lauren Sallan ${ }^{1}$

$3{ }^{1}$ Department of Earth and Environmental Science, University of Pennsylvania, 240 S. $33^{\text {rd }}$ Street,

4 Philadelphia, PA, USA 19104-6316

5

6 Corresponding Authors:

7 Jack Stack ${ }^{1}$

8 stackj@sas.upenn.edu

9

10 Lauren Sallan $^{1}$

11 1sallan@upenn.edu 
12 Abstract - We surveyed the taxa, ecosystems, and localities of the Devonian fishes of Michigan

13 to provide a framework for renewed study, to learn about the diversity and number of these

14 fishes, and to investigate their connection to other North American faunas. Nineteen genera of

15 fishes have been found in the Middle and Late Devonian deposits of Michigan, of which

16 thirteen are 'placoderms' represented by material ranging from articulated head shields to

17 ichthyoliths. As expected from the marine nature of these deposits, 'placoderms' are

18 overwhelmingly arthrodire in nature, but two genera of ptyctodonts have been reported along

19 with less common petalichthyid material. The remaining fish fauna consists of fin-spines

20 attributed to 'acanthodians', two genera of potential crown chondrichthyans, an isolated dipnoan,

21 and onychodont teeth/jaw material. There was an apparent drop in fish diversity and fossil

22 abundance between Middle and Late Devonian sediments. This pattern may be attributed to a

23 paucity of Late Devonian sites, along with a relative lack of recent collection efforts at existing

24 outcrops. It may also be due to a shift towards open water pelagic environments at Late

25 Devonian localities, as opposed to the nearshore reef fauna preserved in the more numerous

26 Middle Devonian localities. The Middle Devonian vertebrate fauna in Michigan shows strong

27 connections with same-age assemblages from Ohio and New York. Finally, we document the

28 presence of partially articulated vertebrate remains associated with benthic invertebrates, an

29 uncommon occurrence in Devonian strata outside of North America. We anticipate this new

30 survey will guide future field work efforts in an undersampled yet highly accessible region that

31 preserves an abundance of fishes from a critical interval in marine vertebrate evolution. 
major transitions in vertebrate biodiversity, including the takeover of ecosystems by jawed

fishes, the first appearance of tetrapods, and several group-specific and global extinctions

(Friedman and Sallan, 2012; Ogg et al., 2016). Despite the evolutionary importance of this interval, Devonian vertebrates from the U.S. have been undersampled and understudied in the last 50 years relative to specimens of the same age from the U.K., China, Australia and even Antarctica (Long, 1995), with possible exceptions being select very Late Devonian faunas such as the Cleveland Shale and Red Hill (Elliott et al., 2000; Carr and Jackson, 2008; Daeschler and Cressler, 2011). Fishes are common in fossil-bearing Paleozoic strata throughout the midwestern U.S., with many outcrops discovered over a century ago (Newberry, 1889; Eastman, 1907; Eastman, 1908; Elliott et al., 2000). The Devonian-aged vertebrate fauna from Michigan is abundant, but is poorly documented in the scientific literature relative to similar strata in Ohio, Pennsylvania and elsewhere, despite heavy, ongoing collection efforts by amateurs (Elliott et al., 2000). We undertook this survey of Devonian fishes from Michigan, the first since 1970, as a result of new discoveries by J.S. (with the assistance of avocational 53 paleontologists). During the Devonian, the Michigan Basin was located between, and connected to, the better described Illinois (Hussakof, 1913; Cluff, 1980; Brusatte, 2007) and Appalachian Basins (Newberry, 1873; Claypole, 1883; Carr and Jackson, 2008; Carr and Hlavin, 2010; Downs et al., 2011; Daeschler and Cressler, 2011), yet it has been largely ignored by researchers for over a century. Most of the handful of studies on Devonian vertebrates from Michigan are descriptions 
59 of single taxa (e.g. Stevens, 1964; Miles, 1966; Schultze, 1982; Carr and Jackson, 2005). Only

60 one study from the last century attempted to survey Devonian fossil fishes from Michigan, but

61 was limited in scope to arthrodires (Case, 1931). Several decades later, an additional summary of

62 vertebrate fossils from the University of Michigan Museum of Paleontology was published by

63 Dorr and Eschman (1970), accompanied by a description of the Devonian ecosystems in

64 Michigan, including information on collecting sites, geologic history, and invertebrate faunae.

65 However, many of their identifications were incorrect, and some of their figured and described

66 specimens are currently missing from the UMMP collections.

Recent fieldwork in Michigan, undertaken mostly by amateur collectors, has revealed a

diverse and in many ways distinct Devonian vertebrate fauna containing taxa not reported by

Case (1931) and Dorr and Eschman (1970). New sites have produced an abundance of relatively

well-preserved vertebrate skeletal remains, including articulated material. Of the 201 Devonian

vertebrate specimens from Michigan that are catalogued in museums, 118 were collected by J.S.

after the previous survey. Here, we provide an updated and comprehensive summary of what is

known about the Devonian fish fauna from Michigan. We also compare the Devonian fish fauna

of Michigan to similarly aged marine faunas from New York and Ohio, placing it within the

75 larger regional context of the Devonian of North America.

\section{MATERIALS AND METHODS}

We surveyed Michigan Devonian fish specimens in the collections of the University of

81 University Museum (VP), the Cleveland Museum of Natural History (CMNH), and the literature, 
82 which contains records for other specimens from the Michigan State University Museum, the

83 Cleveland Museum of Natural History, and the Great Lakes Area Paleontological Museum

84 (GLAPM). We also performed surveys of known outcrops as described in text. Collections from

85 localities on public lands were approved by the State of Michigan, State Historic Preservation

86 Office Permit AE2016-10, and collections were deposited in the Michigan Historical Museum.

87 We compiled and organized information including type specimen, specimen counts, geologic

88 setting and localities (full list of localities available in supplemental files). A full list of examined

89 specimens is available as a supplement. Below, we describe the occurrence and distribution of

90 vertebrate remains by formation alongside information on associated invertebrate remains,

91 depositional environment, and the locations of vertebrate-bearing fossil sites. We also summarize

92 the characteristics of Devonian vertebrates resident in Michigan. We then synthesized temporal

93 patterns, ecology, and faunal similarities with other marine Devonian localities.

94 and Onychodus sp., the stem-chondrichthyan 'acanthodian' Machaeracanthus sp. Newberry, 106

\section{MIDDLE DEVONIAN GEOLOGICAL DISTRIBUTION}

\author{
Pre-Traverse Group
}

The oldest vertebrate bearing Devonian localities in Michigan are from the Eifelian

(Middle Devonian; 393.3-387.7 Ma) (Swezey, 2002; Brett et al., 2011; Ogg et al., 2016; Fig.

1; Fig. 2). These occur in the Dundee Limestone formation, which has also produced

numerous invertebrate remains (Dorr and Eschman, 1970; Ehlers and Kesling, 1970). The fish

found in the Dundee Limestone include the onychodont Onychodus sigmoides Newberry, 1873

1873, the chondrichthyan Acondylacanthus gracillimus St. John and Worthen, 1875, the 
107 presumptive arthrodire ?Titanichthys sp. Newberry, 1885, the ptyctodont Ptyctodus sp. Pander,

108 1858, and the petalichthyid ?Macropetalichthys sp. Norwood and Owen, 1846 (Dorr and

109 Eschman, 1970; Fig. 3). ?Titanichthys sp. (UMMP 26114), A. gracillimus (UMMP 26523),

110 and Machaeracanthus sp. (UMMP 26111, UMMP 26112) and a jaw (UMMP 26113) from

111 Onychodus sp. are known from Sibley Quarry, Wyandotte, Wayne County (Dorr and

112 Eschman, 1970; Table 1). An isolated fin spine from Machaeracanthus sp. (UMMP 3521) and

113 an isolated tooth from O. sigmoides (UMMP 22006; Fig. 3A) are documented from a site in

114 London Township, Monroe County (Dorr and Eschman, 1970). One specimen of two

115 articulated armor plates (UMMP 14320; Fig. 3B) from ?Macropetalichthys sp. and another

116 specimen of Ptyctodus sp. (UMMP 14321) are documented from a locality near Trenton, in

117 Wayne County (Dorr and Eschman, 1970). It is important to note that the geological source of

118 the Ptyctodus specimen is uncertain and cannot be verified based on the matrix (Dorr and

119 Eschman, 1970). Despite this taxonomic diversity, vertebrate abundance and perhaps

120 preservation potential within the Dundee Limestone appears to be very poor (Ehlers and

121 Kesling, 1970).

122

123

The Traverse Group

124

The Traverse Group encompasses all but two of the known vertebrate-bearing formations

125 from Michigan (Dorr and Eschman, 1970; Fig. 1). It was deposited in the Givetian (387-382.7

$126 \mathrm{Ma}$ ), or the Erian (391.8-388 Ma) regional series (Swezey, 2002; Gradstein et al., 2004; Ogg et

127 al., 2016; Fig. 2). Six separate depositional environments or zones have been sampled from the

128 Traverse group, representing different water depths: a lagoonal zone, the zone of turbulence, the 
129 stromatoporid-coral zone, the coral-brachiopod zone, the diverse fauna zone, and a bioherm

130 (Ehlers and Kesling, 1970). These zones were identified and described by Ehlers and Kesling

131 (1970), and are briefly summarized here for future reference. The stromatoporid-coral zone was

132 nearshore, shallow, and contained invertebrates such as brachiopods and crinoids (Ehlers and

133 Kesling, 1970). The coral-brachiopod zone represents deeper water coincident with the lowest

134 limit of stromatoporoids, with fossil material consisting mostly of brachiopods, corals, and

135 bryozoans (Ehlers and Kesling, 1970). Rocks from both of these zones are abundant in the

136 Traverse Group, and tend to be medium to fine grained limestones that can grade down into

137 calcareous shales (Ehlers and Kesling, 1970). The diverse fauna zone was reefal with abundant

138 vertebrates, brachiopods, trilobites, and crinoids with less common corals, bryozoans, and

139 mollusks (Ehlers and Kesling, 1970). The rocks from the diverse fauna zone tend to be thick

140 claystones or shale beds, with low calcareous content (Ehlers and Kesling, 1970). It is also

141 possible to find fish and invertebrate fossils in the lagoonal sediments, but these may have been

142 the result of marine incursions rather than distinct faunas (Stevens, 1964; Ehlers and Kesling,

143 1970). The rocks from the lagoonal zone are lithographic limestone (Ehlers and Kesling, 1970).

Vertebrate Distribution in Early Erian (Givetian) Deposits

148

149 Bell Shale.- One tooth plate (UMMP 14460) from Ptyctodus sp. has been reported

150 from the Bell Shale of Rogers City, Presque Isle County (Dorr and Eschman, 1970).

151 Invertebrate material suggests that the Bell Shale was deposited in the diverse fauna zone

152 (Pohl, 1930; Ehlers and Kesling, 1970). 
154 include the arthrodires Protitanicthys rockportensis Case, 1931, ?Holonema rugosum

155 Claypole, 1883, Holonema sp. Newberry 1889, Dunkleosteus sp. Lehman, 1956, Mylostoma

156 sp. Newberry, 1883 and Dinomylostoma sp. Eastman, 1906, the ptyctodont Ptyctodus sp., the

157 'acanthodian' ?Machaeracanthus sp., and the chondrichthyan ?Tamiobatis sp. Eastman, 1897a

158 (Dorr and Eschman, 1970; personal observation; Fig. 4). There are also two specimens (7M,

159 VP. 522) of placoderms of unknown affinity that have been collected from the Rockport

160 Quarry Limestone. One of these specimens (7M) consists of armor fragments distinguishable

161 from other resident taxa by a lack of tubercles (Fig. 4B), but further material is required to

162 make an exact attribution. Also, a single specimen (UMMP 3898) was given an uncertain

163 designation as ?Holonema rugosum by Dorr and Eschman (1970).

The Rockport Quarry Limestone contains the most diverse Devonian vertebrate fauna in

165 Michigan (Dorr and Eschman, 1970; Sallan and Coates, 2010). The main vertebrate-bearing

166 outcrop is at the abandoned Kelly Island Limestone Quarry at Rockport State Park, Alpena

167 County (Dorr and Eschman, 1970). The degree of preservation is often good, with partially

168 articulated armor plates frequently observed in the field, but mining operations have damaged

169 many of the accessible fossils (personal observation). Fortunately, this locality is the most

170 productive Devonian vertebrate site in Michigan by far (personal observation), and better

171 specimens are likely to be recovered in the future. Despite the relatively high diversity and

172 abundance of fish material and collection efforts by amateurs, little material has been

173 accessioned in state museums. The UMMP contains only single specimens of

174 ?Machaeracanthus sp. (UMMP 13047), Dunkleosteus sp. (UMMP 16152; Fig. 4C), 
176 13147). There are 59 specimens of $P$. rockportensis and 26 specimens of Holonema sp.

177 deposited in UMMP, MSU and the MHM, and many more recently recovered fossils of those

178 fishes reside in private collections (personal observation). The large numbers of

179 stromatoporoids and corals, alongside less common brachiopods, trilobites, and crinoids,

180 suggests that the vertebrate bearing rocks of the Rockport Quarry Limestone were deposited in

181 the stromatoporoid-coral zone (Ehlers and Kesling, 1970). In contrast to most Devonian sites,

182 articulated vertebrate remains are often preserved in conglomerates with invertebrate

183 specimens (personal observation). It is notable that the abundance and diversity of coincident

184 invertebrates is considerably lower than the underlying Bell Shale, most likely because of the

185 difference in depositional zone (Ehlers and Kesling, 1970).

186 Genshaw Formation.- A single specimen of an incomplete armor plate (UMMP 4169)

187 from the ptyctodont ?Eczematolepis sp. Miller, 1892 has been documented from the Genshaw

188 Formation near Posen, Presque Isle County (Dorr and Eschman, 1970). In addition, a specimen

189 of ?H. rugosum (UMMP 3899) has been reported from the Killians member of the Genshaw

190 Formation, at a locality referred to as French Road near Long Lake, near Rockport Quarry,

191 Alpena County (Dorr and Eschman, 1970). Invertebrates found in this formation are typical of

192 the diverse fauna zone (Ehlers and Kesling, 1970).

193

197 Newton Creek Limestone.- A single specimen of the lungfish (dipnoi) Chirodipterus

198 onawayensis (unnumbered) Schultze, 1982, along with two specimens of Machaeracanthus sp. 
199 (UMMP 47691 and UMMP 47692) and two specimens of Holonema farrowi Stevens, 1964

200 (UMMP 46647, UMMP 46648) are documented from the Newton Creek Limestone (Stevens,

201 1964; Dorr and Eschman, 1970; Schultze, 1982). These fossils were collected from the north

202 edge of the Onaway Stone Quarry, Presque Isle County, where the Newton Creek Limestone is

203 referred to as the Koehler Limestone (Dorr and Eschman, 1970; Ehlers and Kesling, 1970).

204 While these fishes were recovered from the lagoonal zone (Stevens, 1964), some may have

205 been deposited during a deeper marine incursion (Ehlers and Kesling, 1970).

206 Gravel Point Formation.- This formation has produced single catalogued specimens of

207 Gyracanthus sp. Woodward, 1906 (UMMP 1329) ?Onychodus sp. (UMMP 14370) (Dorr and

208 Eschman, 1970), and a holonemiid (UMMP 3129) (Dorr and Eschman, 1970). These

209 specimens were found at South Point (Gravel Point), Little Traverse Bay, Charlevoix County

210 (Ehlers and Kesling, 1970). The invertebrate fossils from this formation are typical of the

211 diverse fauna zone (Pohl, 1930; Ehlers and Kesling, 1970).

212 Alpena Limestone Formation. - This formation was deposited contemporaneously with

213 the Gravel Point Formation (Ehlers and Kesling, 1970). Single specimens of Dunkleosteus sp.

214 (UMMP 16152) and Ptyctodus sp. (UMMP 16157), along with three specimens of ?Mylostoma

215 (BV3, BV6, and BV7) and a single specimen of some partially articulated pieces of armor from

216 the head shield of ?Macropetalichthys sp. (BV 4) comprise the catalogued vertebrate material

217 from the Alpena Limestone (Dorr and Eschman, 1970). The specimens of Dunkleosteus sp. and

218 Ptyctodus sp. are from a locality referred to as Alkali Quarry in Alpena, and the ?Mylostoma sp.

219 and ?Macropetalichthys sp. specimens are from the Besser Museum Fossil Park in Alpena

220 (personal observation; Dorr and Eschman, 1970). Amateur collectors have reported $P$. 
221 rockportensis and other vertebrates from this formation, but none of these specimens are

222 deposited in museum collections. The invertebrate fossils from this formation are typical of the

223 coral-brachiopod zone. (Pohl, 1930; Ehlers and Kesling, 1970). Many of these are articulated

224 and occur in conglomerates with similarly partially articulated vertebrate specimens.

225

226

227

228

229

230

231

232

233

234

235

236

237

238

239

240

241

242

243

244

Vertebrate Distribution in Late Erian (Givetian) Deposits

Four Mile Dam Formation.— ?Mylostoma sp., P. rockportensis, ?Macropetalichthys sp. and an unidentified 'acanthodian' and 'placoderm' have recently been collected by one of the authors (JS) from the Four Mile Dam Formation (Fig. 5). At this time, ?Mylostoma sp. is known from 39 specimens, while an unidentified 'placoderm' is known from one specimen (JS 4; Fig. 5C), an unidentified 'acanthodian' is known from two partial fin spines (JS 120, JS 121; Fig. 5A), P. rockportensis is known from one specimen of an armor fragment (JS 101), and ?Macropetalichthys sp. is known from a partial head shield (32M). The unidentified placoderm (JS 4) is a specimen of an armor plate that does not resemble the other resident placoderms (?Mylostoma sp., P. rockportensis, and ?Macropetalichthys sp., Fig. 5C). More material needs to be collected before a concrete identification is made. Likewise, the two isolated acanthodian fin spines are distinct from named acanthodians (Gyracanthus, Machaeracanthus, and Oracanthus) and chondrichthyans (Tamiobatis and Acondylacanthus) reported from Michigan (J.S. personal observation; Denison, 1979; Maisey 1982; Williams, 1998). The vertebrate fauna from the Four Mile Dam Formation has high abundance but low diversity compared to the Rockport Quarry Limestone (Dorr and Eschman, 1970). The main vertebrate-bearing outcrop of this formation is the Specific Stone Products Quarry in Alpena, with the fossils recovered 
245 from discarded piles of limestone from this quarry on the shores of Betsie Bay in Elberta,

246 Benzie County (J.S. personal observation).

247 Despite the fact that the Four Mile Dam Formation was only recently identified as a

248 vertebrate-bearing formation, fish material may be more abundant in these sediments than at

249 any other Devonian locality in Michigan. There have been 44 vertebrate specimens recovered

250 in a few years of limited yet deliberate collecting in rocks from this formation. However, this

251 represents more recent collection effort by university-affiliated researchers than has recently

252 been expended at other Michigan sites. Many of the Four Mile Dam ?Mylostoma sp. specimens

253 are well-preserved and partially articulated, including potential juveniles, suggesting that this

254 locality holds high potential for future research (personal observation). The degree of

255 preservation suggests rapid burial, perhaps by a mudflow initiated by a storm given the

256 environmental setting. This interpretation is supported by the fact that of the vertebrate

257 specimens from this formation are found in conglomerates with invertebrate specimens (Fig.

258 5D). This includes fully three-dimensional, articulated crinoid calyces, a rarity in the Devonian

259 record that requires quick deposition (Fig. 5D). These invertebrates are found in other outcrops

260 of the Four Mile Dam Formation, but fish fossils are absent from all but the site mentioned

261 above (Dorr and Eschman, 1970; Ehlers and Kesling, 1970), implying that vertebrate material

262 may not be preserved in this formation under more normal environmental conditions.

263 Invertebrate fossils found in this formation are typical of the diverse fauna zone (Ehlers and

264 Kesling, 1970).

265 Norway Point Formation.- A single spine (UMMP 23495), attributed to the acanthodian

266 Oracanthus sp. Agassiz, 1843, has been reported from the Norway Point formation at the Four 
267 Mile Dam, 6 kilometers northwest of Alpena, Alpena County (Ehlers and Kesling, 1970, Dorr

268 and Eschman, 1970). The invertebrates from this formation suggest that the rocks were

269 deposited in the coral-brachiopod zone (Ehlers and Kesling, 1970).

270 Potter Farm Formation.-- One specimen of Ptyctodus sp. (UMMP 21718) is known from

271 the Potter Farm Formation, recovered from a locality referred to by Dorr and Eschman (1970) as

272 “Old Wamer's Brickyard", southwest of Alpena, Alpena County. However, Dorr and Eschman

273 (1970) noted that the exact geologic affinity of this specimen is uncertain (it may not have been

274 collected in situ). However, another specimen of Ptyctodus sp. (UMMP 21817) was collected

275 from an outcrop of the Potter Farm Formation at the "west edge of Alpena Cemetery", Alpena

276 (Dorr and Eschman, 1970). Amateur collectors have also reported specimens of P. rockportensis

277 from this formation, but these specimens are not deposited in museum collections and therefore

278 cannot be verified. The invertebrate fossils found from the Potter Farm Formation are typical of

279 the diverse fauna zone (Ehlers and Kesling, 1970). Many of these invertebrates are again

280 preserved in conglomerates with vertebrates, as in the Four Mile Dam Formation (Fig. 5D).

281 These invertebrate specimens are occasionally broken and preserved in a way that superficially

282 resembles dark, thin armor plates from vertebrates, and have been misidentified as such by

283 amateurs, so caution must be used when identifying specimens from this formation without

284 attention to histology.

285 Thunder Bay Limestone.- A tooth plate (UMMP 3023) from Ptyctodus sp. has been

286 reported from the Thunder Bay Limestone (Dorr and Eschman, 1970). This specimen was

287 collected from the bluffs on the northeast shore of Partridge Point, 6.4 kilometers south of

288 Alpena (Dorr and Eschman, 1970). The invertebrates from this formation are typical of the

289 diverse fauna zone (Pohl, 1930; Ehlers and Kesling, 1970). 
291

292

293

294

295

296

297

298

299

300

301

302

303

304

305

306

307

308

309

310

311

312

313

314

315

\section{LATE DEVONIAN GEOLOGICAL DISTRIBUTION}

Antrim Shale.- The Antrim Shale was deposited in the Frasnian (382.7-372.2 Ma), or

Senecan (388-370 Ma) regional series and in the Famennian (372.2-358.9 Ma), or the

Chatauquan (370-359.2 Ma) regional series of the Late Devonian (Dorr and Eschman, 1970;

Ehlers and Kesling, 1970; Gutshick and Sandberg, 1991; Gradstein et al., 2004; Ogg et al., 2016;

Fig. 1; Fig. 2). Fish from the Antrim Shale that are accessioned in museum collections include $D$. lafargei Carr and Jackson, 2005, ?Trachosteus clarki Newberry, 1889, Dunkleosteus sp., and Aspidichthys clavatus Newberry, 1873, all known only from single specimens (Dorr and Eschman, 1970; Carr and Jackson, 2005). There are also reports of the presence of ptyctodonts, cladodonts (Chondrichthyes), conodonts, and ray-finned fishes from the Antrim Shale (Ehlers and Kesling, 1970; Elliott et al., 2000). It is not clear if these specimens are deposited in museum collections, and therefore they were not examined in this study. ?T. clarki is known from an isolated inferognathal (UMMP 18206) from a locality 1.6 kilometers north of Norwood, Charleviox County (Dorr and Eschman, 1970). The armor plate (UMMP 3127) of A. clavatus was collected from the shore of Grand Traverse Bay near Norwood (Dorr and Eschman, 1970). Dunkleosteus is known from a suborbital plate (UMMP 15432) found in a concretion nodule from Squaw Bay, 6.4 kilometers south of Alpena on U.S. 23 (Dorr and Eschman, 1970). D. lafargei is known from an incomplete, disarticulated specimen (CMNH 50215) from Paxton Quarry (Lafarge North America, Inc., Alpena Cement Plant, Great Lakes Region), Alpena (Carr and Jackson, 2005).. Invertebrate fossils from this formation include brachiopods and cephalopods (ammonoids), demonstrating relatively low invertebrate diversity compared to Middle Devonian formations (Ehlers and Kesling, 1970; Gutshick and Sandberg, 1991; Hannibal 
316 et al., 1992). This is likely reflective of the open water habitat the Antrim Shale was deposited in,

317 a contrast to the reefs and nearshore depositional environments of Michigan's Middle Devonian

318 localities (Gutshick and Sandberg, 1991). The Antrim Shale is a typical Late Devonian North

319 American black shale, containing large quantities of black mud rich in organic matter from

320 deposition on a poorly oxygenated ocean floor (Dorr and Eschman, 1970; Roen 1984).

321

322

323

324

325

326

327

328

329

330

331

332

333

334

335

336

337

338

339

\section{THE ENVIRONMENT AND ASSEMBLAGES OF DEVONIAN MICHIGAN}

During the Middle Devonian, Michigan was located underneath a shallow, tropical sea

(Dorr and Eschman, 1970). Most Middle Devonian localities are associated with these reef

formations due to abundant invertebrate life and bioherm construction, contributing to rock

formation (Ehlers and Kesling, 1970). Much of the center of the Lower Peninsula is covered

with a thick layer of glacial till, preventing detailed paleontological study (Lilienthal, 1978).

Sites situated along the northern edge of the Lower Peninsula give a fairly good window into

the structure of Michigan's Middle Devonian ecosystems (Ehlers and Kesling, 1970; Dorr and

Eschman, 1970). These sites present diverse invertebrate biotas including crinoids, trilobites, cephalopods, gastropods, corals, bryozoans, brachiopods, and blastoids (Pohl, 1930; Ehlers

and Kesling, 1970). The vertebrate fauna includes numerous 'placoderms' (arthrodires, petalichthyids, and ptyctodonts), chondrichthyans (ctenacanths), lungfish, onychodonts, and 'acanthodians' (Dorr and Eschman, 1970).

Vertebrate material, most of it at least partially articulated, from the Devonian of 
340 Michigan is usually associated with numerous benthic shelled invertebrates, unlike most sites

341 of similar age outside of North America (Ehlers and Kesling, 1970; personal observation).

342 This type of assemblage is also found in similarly-aged Columbus and Delaware Limestones

343 of Ohio (Eastman, 1907; Westgate and Fischer, 1933; Wells, 1944; Denison, 1978; Martin,

344 2002). In several formations, fishes and invertebrates are found in association within the

345 same conglomerate or slab (Fig. 5D).

346 Michigan's faunas exhibited changes in the number, type, and diversity of fossils from the

347 Middle to Late Devonian. Most Late Devonian non-vertebrate fossils are cephalopods,

348 brachiopods, and assorted plant fossils, marking a significant change from the rich invertebrate

349 fauna from the Middle Devonian (Ehlers and Kesling, 1970; Hannibal et al., 1992). In addition,

350 the vertebrate assemblage in the Late Devonian is dominated by arthrodire and ptyctodont

351 'placoderms,' which is a much less diverse fish fauna than what was present in the Middle

352 Devonian (Dorr and Eschman, 1970; personal observation). As noted above, the Antrim Shale

353 was deposited in an open water pelagic habitat with little to no benthic community (Gutshick

354 and Sandberg, 1991). There was likewise a shift in rock types from primarily limestone in the

355 Middle Devonian to an alternating pattern of shale and limestone in the Late Devonian (Dorr

356 and Eschman, 1970). The Antrim Shale, the only vertebrate-bearing formation from the Late

357 Devonian in Michigan, is constructed in this manner (Dorr and Eschman, 1970; Gutshick and

358 Sandberg, 1991). This alteration suggests that sea levels shifted several times during this

359 interval, which would have contributed to the loss of older reef structures and upwelling of

360 anoxic waters for shale deposition (Roen, 1984; Sandberg et al., 2002). Similar black shale

361 deposition has been recorded from the Devonian of other areas of North America, such as New 
362 York, Tennessee, Ohio, and Kentucky (Roen, 1984). In Michigan, coral reefs disappear at the

363 base of the Frasnian with the deposition of black shales (Ehlers and Kesling, 1970). This loss

364 precedes bioherm elimination in other regions of the world, where corals are virtually

365 eliminated by the climate-driven Frasnian-Famennian Kellwasser events (Kiessling et al., 2010).

366

367

368

369

370

371

372

373

374

375

376

377

378

379

380

381

382

383

384

385

386

387

\section{DEVONIAN FISHES OF MICHIGAN}

Here we describe what is known about the occurrence and distribution of major vertebrate clades and lineages from the Devonian of Michigan. Because of the aforementioned absences in the record and new discoveries, much of the information comes from personal observation as noted.

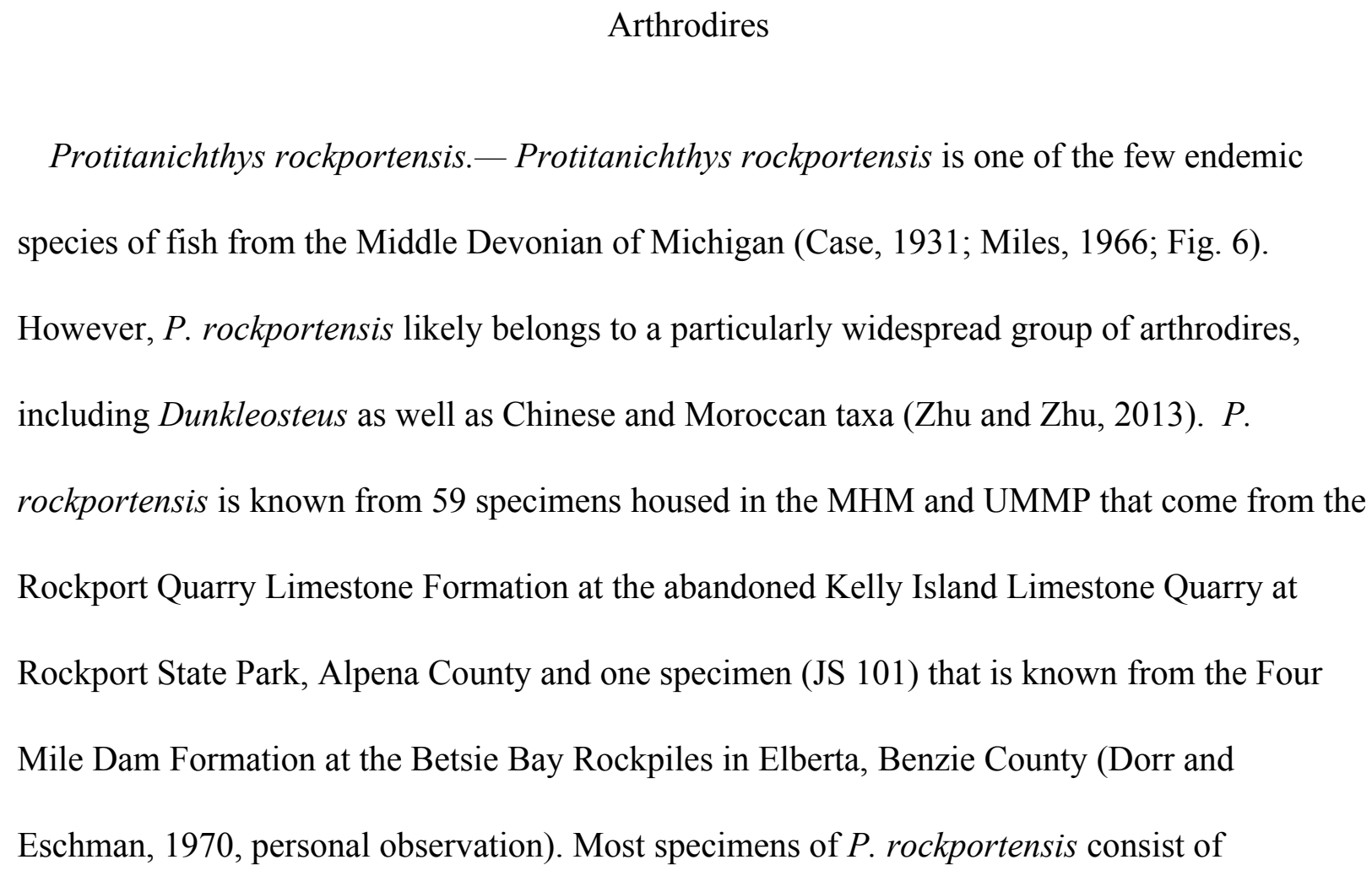
including Dunkleosteus as well as Chinese and Moroccan taxa (Zhu and Zhu, 2013). P. rockportensis is known from 59 specimens housed in the MHM and UMMP that come from the Rockport Quarry Limestone Formation at the abandoned Kelly Island Limestone Quarry at Rockport State Park, Alpena County and one specimen (JS 101) that is known from the Four Mile Dam Formation at the Betsie Bay Rockpiles in Elberta, Benzie County (Dorr and Eschman, 1970, personal observation). Most specimens of P. rockportensis consist of 
388 disarticulated and incomplete pieces of dermal bone from the head shield (Miles, 1966; Figure

389 6C). The poor quality and lack of articulation in these specimens is caused by breakage during

390 quarrying operations, scavenging, and high-energy water flow in the environment of deposition

391 (Ehlers and Kesling, 1970; personal observation). The majority of the specimens are from fish

392 that would have been about a meter in length in life, but a few rare individuals may have been

393 over two meters in total length, making them very large for coccosteids (Denison, 1978). Most

394 specimens appear to have been adults, but smaller juveniles and possibly senescent animals

395 have been identified (personal observation). A well-preserved specimen (4M) of the head shield

396 of a small placoderm that resembles Bothriolepis Eichwald, 1840 in size and ornamentation has

397 also been recovered from the Rockport Quarry Limestone at the abandoned Kelly Island

398 Limestone Quarry at Rockport State Park, Alpena County (Fig. 6D). There are also several

399 other small, far less complete specimens from that site bearing similar ornamentation (small,

400 dense tubercles). While these resemble Bothriolepis, they are most likely juvenile specimens of

401 P. rockportensis, as smaller (and presumably younger) P. rockportensis would have had

402 prominent sutures between the plates of their head shield, with their form distinct from larger

403 members of the same species. The relative age of these fishes can be estimated by the

404 distinction of the sutures between the armor plates of the head shield, with older animals

405 bearing less noticeable sutures that fused with age (R. Carr pers. comm. 2012). Better material

406 must be found in order to make a final determination as to these alternative attributions.

407 Because of the relatively high number of specimens, $P$. rockportensis has been described in

408 detail (Miles, 1966).

409 Titanicthys. - ?Titanichthys sp. is known from a single specimen (UMMP 26114) from the 
410 Dundee Limestone of Sibley Quarry, Wyandotte (Dorr and Eschman, 1970). Titanichthys is

411 primarily known from open water settings in the Late Devonian, so it possible that this has been

412 misidentified (Janvier, 2003; Boyle and Ryan, 2017). Indeed, Dorr and Eschman (1970) stated

413 the exact affinity of this specimen was uncertain. Complicating matters further, the specimen is

414 currently missing from museum collections and has never been figured.

415 Holonema. - Two species of Holonema are found in Michigan: H. farrowi and ?H. rugosum

416 (Stevens, 1964; Dorr and Eschman, 1970). Most specimens consist of dorsal and/or ventral

417 shields with distinctive ornamentation of rows and ridges of tubercles, which are easily

418 identifiable even from fragmented remains (Dorr and Eschman, 1970; Fig. 4A). This fish is

419 most common in the Rockport Quarry Limestone at the abandoned Kelly Island Limestone

420 Quarry at Rockport State Park, Alpena County, with 26 specimens registered at UMMP and

421 MHM (Dorr and Eschman, 1970; personal observation). Two specimens of $H$. farrowi (UMMP

42246647 and UMMP 46648) have been reported from the Newton Creek Limestone at Onaway

423 Stone Quarry, north edge of Onaway, Presque Isle County (Dorr and Eschman, 1970). One

424 specimen of ?H. rugosum (UMMP 3899) has been documented from the Genshaw Formation at

425 French Road, near Long Lake, Alpena County (Dorr and Eschman, 1970). A specimen that

426 Dorr and Eschman (1970) designated as a holonemiid was collected from the Gravel Point

427 Formation of South Point (Gravel Point; UMMP 3129). Finally, another specimen (UMMP

428 3130) that was designated as a holonemiid by Dorr and Eschman (1970) was collected from an

429 unknown formation in the quarry that is currently known as the Michigan Limestone and

430 Chemical Company quarry in Rogers City, Presque Isle County (Dorr and Eschman, 1970).

431 The flattened body shape and weak bite of Holonema indicates that it was a bottom feeder 
432 (Miles, 1971; Denison, 1978).

433 Dinomylostoma.-Dinomylostoma sp. is known from eight specimens (UMMP 3046, UMMP

434 12974, UMMP 13042, UMMP 13056, UMMP 13148, UMMP 13041, and UMMP 16158) from

435 the Rockport Quarry Limestone at the abandoned Kelly Island Limestone Quarry at Rockport

436 State Park, Alpena County (Dorr and Eschman, 1970). While the reported specimens of this

437 fish are currently missing from museum collections, one of these (the specimen number was not

438 specified) was figured in Dorr and Eschman (1970) and appears to have been accurately

439 identified.

440 Mylostoma.-Mylostoma sp. was previously known in Michigan from one specimen

441 (UMMP 13612) from the Rockport Quarry Limestone at the abandoned Kelly Island

442 Limestone Quarry at Rockport State Park, Alpena County (Dorr and Eschman, 1970). As with

443 many of the other specimens examined by Dorr and Eschman (1970), this specimen was not

444 figured, and cannot be located in the museum collections, even before the recent move of the

445 UMMP collections. In the last few years, J.S. has recovered 39 specimens of small to

446 medium-sized arthrodires that appear to be from Mylostoma sp. from the Four Mile Dam

447 Formation of the Betsie Bay Rockpiles, in Elberta, Benzie County, three specimens from the

448 Alpena Limestone Formation at the Besser Museum Fossil Park in Alpena (BV3, BV6, and

449 BV7), and one specimen from the Rockport Quarry Limestone at the abandoned Kelly Island

450 Limestone Quarry at Rockport State Park, Alpena County (15M). These are now deposited in

451 the MHM as per the permitting procedure for public lands in Michigan, awaiting transfer to

452 the UMMP. The above specimens resemble Mylostoma in having a thick, rounded median

453 dorsal plate and in lacking ornamentation on the surface of the armor plates (Denison, 1978; 
454 Fig. 5(B)). These specimens are usually partially articulated, which is uncommon for

455 placoderm remains from Michigan, and remains of ventral and head shields are also known.

456 However, positive identification as Mylostoma sp. must await the recovery of gnathal plates

457 (Denison, 1978; personal observation). The size of most of these new specimens suggests that

458 they are most likely juveniles, an inference supported by the coincident collection of a

459 relatively large, poorly preserved specimen (2M) from Four Mile Dam with similar

460 morphology and lack of tubercles (personal observation). If this identification is correct,

461 Mylostoma sp. is currently represented by more specimens than any other fish from the

462 Devonian Michigan.

463 Dunkleosteus. - Dunkleosteus sp. is known from one specimen of a partial impression of a 464 suborbital plate (UMMP 15432) from the Antrim Shale of Squaw Bay, 6.4 kilometers south

465 of Alpena, one specimen of a supragnathal (UMMP 16152) from the Alpena Limestone of the

466 Alkali Quarry of Alpena, one specimen of an incomplete anterior ventrolateral plate (UMMP

467 16156; Fig. 4C) from the Rockport Quarry Limestone at the abandoned Kelly Island

468 Limestone Quarry at Rockport State Park, Alpena County and one specimen (VP.517) from

469 an undetermined site in Alpena (Dorr and Eschman, 1970). These specimens are generally

470 isolated plates, and are not usually articulated. Dorr and Eschman (1970) originally referred to

471 these specimens as Dinichthys sp. Newberry 1868, but this genus has since been synonymized

472 with Dunkleosteus, with the exception of a single species from the Famennian Huron Shale

473 Member of the Ohio Shale Formation (Carr and Hlavin, 2010). Although these specimens are

474 incomplete, the difference in age between the Michigan specimens and Dinichthys herzeri,

475 along with the resemblance they bear to more complete specimens of Dunkleosteus described 
476 by Carr and Hlavin (2010), strongly indicates that they should be attributed to Dunkleosteus $477 s p$.

478 Aspidichthys clavatus. - A. clavatus is known from a single specimen (UMMP 3127) from 479 the Antrim Shale of the shore of Grand Traverse Bay near Norwood, Charlevoix County (Dorr 480 and Eschman, 1970). As above, the reported specimen is missing from museum collections 481 and was not figured, so this identification may not be reliable.

482 Diplognathus lafargei.- D. lafargei is known from the Late Devonian of Michigan (Carr 483 and Jackson, 2005). Unfortunately, the recent flooding of Paxton Quarry means that the lens 484 that produced the holotype of D. lafargei is no longer accessible (R.L. Carr pers. comm. 485 2018). D. lafargei is currently known from an incomplete, disarticulated specimen (CMNH 486 50215) found in a talus slope in Paxton Quarry (Lafarge North America, Inc., Alpena Cement

487 Plant, Great Lakes Region), Alpena (Carr and Jackson, 2005). This specimen includes the 488 suborbital and anterior superognathal plates, along with the right inferognathal, posterior supragnathal, and posterior ventrolateral (Carr and Jackson, 2005).

490 Trachosteus clarki.-?T. clarki is known from a single specimen (UMMP 18206) of a 491 infragnathal plate that was found from the Antrim Shale Formation 1.6 kilometers north of 492 Norwood, Charlevoix County (Dorr and Eschman, 1970; Fig. 7). This specimen was 493 designated as uncertain by Dorr and Eschman (1970), most likely because T. clarki is known 494 solely from a disarticulated and incomplete headshield from the Cleveland shale (Denison, 495 1978). UMMP 18206 resembles the infragnathal of T. clarki in having a low blade and sharp 496 teeth on the biting edge, but there is not enough information available on this fish for this 497 identification to be certain (Denison, 1978). 
501 Macropetalichthys.-? Macropetalichthys sp. is known from a specimen of a spinal and 502 anterior ventrolateral plate (UMMP 14320) from the Middle Devonian of the Dundee 503 Limestone near Trenton (Fig. 3B), a partial headshield (32M; Fig. 8A) from the Four Mile 504 Dam Formation of the Betsie Bay Rockpiles, in Elberta, Benzie County, and from partially 505 articulated plates from the anterior portion of the headshield (BV 4; Fig. 8B) from the Alpena

506 Limestone formation at the Besser Museum Fossil Park in Alpena (Dorr and Eschman, 1970;

507 personal observation). UMMP 14320 was identified by Dorr and Eschman (1970) as

508 Arctolepis sp. Eastman, 1908 based on its elongated spinal plates ornamented with small 509 spines. However, this specimen (Fig. 3B; UMMP 14320) much more closely resembles

510 Macropetalichthys because the spinal plate is not as recurved as those in Arctolepis, the spines

511 on this spinal plate are more numerous and tightly spaced than those in Arctolepis, and because

512 its spines are present on the outer edge of the spinal plate (unlike Arctolepis, where the spines

513 are present on the interior edge of the spinal plate) (Denison, 1978; Janvier, 2003; personal

514 observation). Unfortunately, the specimen does not retain any of the diagnostic features of the

515 genus, so we can only tentatively reattribute it (Eastman, 1907; Denison, 1978). Whatever the

516 case, Macropetalichthys is already known from several localities in North America, including

517 the Delaware and Columbus limestone of Ohio, which were closely associated with Michigan

518 during the Middle Devonian (Eastman, 1907; Denison, 1978; Martin, 2002). Arctolepis,

519 however, is otherwise restricted to the Early Devonian of Spitsbergen (Denison, 1978). The

520 anatomical, temporal, and geographical evidence therefore indicates that UMMP 14320 is far 
521 more likely to be from Macropetalichthys than Arctolepis (personal observation). The rounded

522 anterior portion of the indentation of the headshield in $32 \mathrm{M}$ strongly resembles the narrow,

523 rounded rostral plate in the headshield of Macropetalichthys in shape (Eastman, 1897b;

524 Denison, 1978; Fig. 8A). This specimen also resembles Macropetalichthys in bearing sparse, 525 irregularly arranged tubercles (Denison, 1978; Martin, 2002; Fig. 8A). Similarly, the shape of

526 the plates present in BV 4 also strongly resembles the anterior portion of the headshield of 527 Macropetalichthys (Eastman, 1897b; Denison, 1978; Martin, 2002; Fig. 8B). In particular, one 528 of the plates (labeled R in Fig. 8B) looks very similar to the rounded, blunt rostral plate seen in

529 Macropetalichthys (Denison, 1978). Despite the strong similarity in shape between these 530 specimens and Macropetalichthys, neither of these specimens are complete enough to make 531 their attribution to Macropetalichthys definitive.

Ptyctodontida

535

536

537

Ptyctodus. - Specimens of Ptyctodus sp., consisting of isolated tooth plates, have been found 538 in the Dundee Limestone near Trenton, Wayne County (UMMP 14321), the Bell Shale of Rogers City, Presque Isle County (UMMP 14460), the Thunder Bay Limestone of the bluffs on 539 the northeast shore of Partridge Point, 6.4 kilometers south of Alpena, Alpena County (UMMP 540 3023), the Rockport Quarry Limestone at the abandoned Kelly Island Limestone Quarry at 541 Rockport State Park, Alpena County (UMMP 13045), the Alpena Limestone of Alkali Quarry,

542 Alpena (UMMP 16157), the Potter Farm Formation (uncertain) of "old Wamer's Brickyard" 543 southwest of Alpena (UMMP 21718), and the Potter Farm Formation of the west edge of 544 Alpena Cemetery, Alpena (UMMP 21817; Dorr and Eschman, 1970). Other single specimens 
545 of Ptyctodus are recorded from an unknown formation in Afton Quarry, Cheboygan County

546 (VP.489) and the Traverse Group (unknown formation) of Emmet County (UMMP 14712)

547 (Dorr and Eschman, 1970). While many of these specimens have gone missing since 1970,

548 those figured (specimen numbers not specified) in Dorr and Eschman (1970) suggest their

549 attribution is accurate (personal observation). There are also reports of other ptyctodont

550 remains, including isolated gnathal plates and articulated specimens, from the Antrim Shale

551 (Elliott et al., 2000). However, it is not clear if the specimens this report is based upon are

552 deposited in museum collections, so they cannot currently be verified. The widespread

553 distribution of Ptyctodus fossils may be due to both the higher preservation potential of hard

554 tooth plates and/or association with abundant shelly invertebrates. Relatively poor taxonomic

555 knowledge of Ptyctodus, a wastebin taxon widely applied to various ptyctodont teeth, may also

556 be a contributing factor (Denison, 1978). In general, ptyctodont tooth plates are common, but

557 articulated remains are not (Denison, 1978; Trinajstic and Long, 2009). Therefore, tooth plates

558 form the basis for the majority of ptyctodontid taxa, including Ptyctodus (Denison, 1978;

559 Trinajstic and Long, 2009). Further taxonomic work on existing specimens, and on North

560 American ptyctodonts in general, is required to determine if the specimens from Michigan all

561 originate from the same genus.

562 Eczematolepis. - Eczematolepis sp. is known from a single partial armor plate from

563 (UMMP 4169) from the Genshaw formation, near Posen, Presque Isle County (Dorr and

564 Eschman, 1970; Fig. 9). UMMP 4169 was identified as Bothriolepis sp. by Dorr and Eschman

565 (1970), however we attribute this plate to ?Eczematolepis sp. because its ornamentation of

566 crowded, irregularly arranged, tubercles more closely resembles Eczematolepis (Denison, 
567 1978; Martin, 2002; J.L. pers. comm.). Also, the shape of this plate does not resemble what is

568 seen in Bothriolepis (J.L. pers. comm). This specimen is not complete enough to make an exact

569 identification, so we designate it as uncertain. Besides this specimen, Dorr and Eschman

570 (1970) identified a large supragnathal plate (UMMP 14374; Fig. 10) from an unknown

571 formation in the Traverse Group of a locality in Alpena, Alpena County as Eczematolepis sp..

572 The locality this specimen was recovered from is referred to by Dorr and Eschman (1970) as

573 "Locality 650 of the Winchell Survey", but no other information is available on its geological

574 context. While this specimen appears to the supragnathal of a ptyctodont, Eczematolepis is

575 known only from head or body plates (Denison, 1978). Furthermore, there is uncertainty

576 surrounding whether or not Eczematolepis is a ptyctodont (Denison, 1978; J.L. pers comm.).

577 Therefore, although this specimen can be concretely identified as a ptyctodont, it cannot be

578 attributed to Eczematolepis. A general lack of taxonomic information for ptyctodonts from the

579 Eifelian of North America means that this specimen cannot be identified at a finer taxonomic

580 level at this point in time (Martin, 2002).

581

582

583

584

585

586

587

588

589

590

\section{'Acanthodii'}

Gyracanthus. - Gyracanthus sp. is known from one specimen (UMMP 1329) from the Gravel Point Formation of South Point (Gravel Point), Little Traverse Bay, Charlevoix County (Dorr and Eschman, 1970). This specimen is currently missing from the UMMP and was not figured by Dorr and Eschman (1970). This spine-based identification is therefore not verifiable, particularly as Devonian specimens of this widespread Carboniferous genus are dubious and in need of re-examination (Turner et al., 2005). 
591 Machaeracanthus.-Machaeracanthus sp. is reported from one specimen (UMMP 3521)

592 from the Dundee Limestone of Monroe County, two specimens (UMMP 26111 and UMMP

593 26112) from the Dundee Limestone of Sibley Quarry, Wyandotte, Wayne County, one

594 specimen (UMMP 13047) of uncertain status from the Rockport Quarry Limestone at the

595 abandoned Kelly Island Limestone Quarry at Rockport State Park, Alpena County, and two

596 specimens (UMMP 47691 and UMMP 47692) from the Newton Creek Limestone at Onaway

597 Stone Quarry, Presque Isle County (Dorr and Eschman, 1970, personal observation; Fig. 11).

598 The specimen from the Rockport Quarry Limestone (UMMP 13047) was identified as $A$.

599 gracillimus by Dorr and Eschman (1970), but an examination of the specimen demonstrated

600 significant differences in the structure of this spine compared to what is known from $A$.

601 gracillimus (Maisey, 1983). This spine is long and thick with a smooth surface, and therefore

602 much more closely resembles the spines of Machaeracanthus (Denison, 1979; Maisey, 1983;

603 Fig. 11B). As shown by the specimen list (available in the supplemental files),

604 Machaeracanthus is relatively common in the Middle Devonian of Michigan and closely

605 associated areas (Eastman, 1907; Wells, 1944; Dorr and Eschman, 1970; Denison, 1978). In

606 contrast, A. gracillimus is known only from the Carboniferous of Iowa in North America,

607 after a major mass extinction event (Wellburn, 1901; Zangerl, 1981; Maisey, 1983; Itano et

608 al., 2003; Elliott et al., 2004; Brusatte, 2007; Sallan and Coates, 2010).

609 Oracanthus.-Oracanthus sp. is known from a fin spine (UMMP 23495) from the Norway

610 Point Formation of the Four Mile Dam, about 5.6 kilometers northwest of Alpena, Alpena

611 County (Dorr and Eschman, 1970). As above, this specimen was unfigured by Dorr and

612 Eschman (1970) and it is missing, so we cannot verify its identity. 
617 Acondylacanthus.- A fin spine specimen of $A$. gracillimus (UMMP 26523) was collected

618 from the Dundee Limestone of Sibley Quarry, Wyandotte, Wayne County, (Dorr and Eschman,

619 1970). This specimen is now missing from the UMMP, so we cannot determine if this

620 identification is reliable or if it was misidentified in the same way as UMMP 13047. This

621 would be the earliest reported specimen of Acondylacanthus by far; other occurrences are

622 clustered in the Carboniferous of the U.S. and the U.K. (Wellburn, 1901; Maisey, 1983; Itano

623 et al., 2003; Elliott et al., 2004; Brusatte, 2007).

624 Tamiobatis. - ?Tamiobatis sp. is a small chondrichthyan reported from one specimen

625 (UMMP 13147) of a fin spine from the Rockport Quarry Limestone at the abandoned Kelly

626 Island Limestone Quarry at Rockport State Park, Alpena County (Dorr and Eschman, 1970;

627 Fig. 4D). Dorr and Eschman (1970) identified this spine as Ctenacanthus Agassiz 1835, but

628 comparisons of this specimen with more recent descriptive work disputes this attribution

629 (Maisey, 1982; Williams, 1998). This specimen more closely resembles a fin spine

630 impression from Tambiobatis from the Cleveland Shale (Williams, 1998). More complete

631 material from Michigan is needed to make a concrete diagnosis, so this assignment is

632 designated as uncertain.

633

634

635

636

637

638

\section{Onychodontiformes}


640 (Dorr and Eschman, 1970), including the Dundee Limestone of London Township, Monroe

641 County (UMMP 22006; Fig. 3A), Sibley Quarry, Wyandotte, Wayne County (UMMP 26113) as

642 well as an uncertain specimen from the Gravel Point Formation of the shore of the Little

643 Traverse Bay, Charlevoix County (UMMP 14370) (Dorr and Eschman, 1970). UMMP 22006

644 was identified to the species level, O. sigmoides (Dorr and Eschman, 1970). In most cases, the

645 genus is represented solely by its large distinctive tooth whorls, with the exception of one lower 646 jaw (UMMP 26113; Dorr and Eschman, 1970).

647

648

649

650

651

652

653

654

655

656

657

658

659

660

661

662

663

664

665

\section{Dipnoi}

\section{Chirodipterus onawayensis. - C. onawayensis is the only lungfish known from the}

Devonian of Michigan, and thus far is represented by a single specimen which was preserved well enough to allow diagnosis as a new species (Schultze, 1982; Long, 1995). The holotype of C. onawayensis represents the left side of the skull and jaws, and was collected from the Onaway Stone Quarry, which is north of Onaway in Presque Isle County (Schultze, 1982; Fig. 12). This specimen was unnumbered at the GLAPM and appears to be missing (Schultze, 1982). It is similar to Chirodipterus australis Miles, 1977 from Gogo in Australia, and possesses the powerful jaws typical of a durophagous Devonian lungfish (Schultze, 1982; Long, 2011).

\section{DISCUSSION}

Despite proximity to major research institutions and collections, the rich reef and 
666 nearshore faunas of the Middle Devonian of North America have been neglected in recent

667 decades, particularly relative to similarly-aged localities in even more remote areas of

668 Antarctica, Australia, and Morocco (Gardiner, 1984; Derycke et al., 1995; Blieck and

669 Lelievre, 1995; Elliott et al., 2000; Janvier, 2003; Rücklin, 2010; Sallan and Coates, 2010;

670 Friedman and Sallan, 2012). There are significant gaps in the total Devonian record in

671 Michigan, with vertebrates in some intervals, particularly the Late Devonian, poorly

672 represented and deficient in number relative to similarly-aged horizons in Ohio (Dorr and

673 Eschman, 1970; Carr and Jackson, 2008). Complicating matters, a large proportion of

674 previously published and catalogued specimens could not be located in the paleontological

675 collections at the University of Michigan, leaving only brief and incomplete documentation

676 as proof of their existence (Dorr and Eschman, 1970). In addition, a large number of more

677 recently recovered specimens are resident in amateur collections - the result of a lack of

678 professional efforts in the state in recent decades - and cannot be used for scientific

679 purposes.

680 Never-the-less, examination of available new and old material shows that Michigan is much

681 richer in diversity and sheer number of fish specimens than previously thought. This has

682 revealed several previously unreported but likely significant biogeographical and diversity

683 patterns, including a shift in environment and faunas between the Middle and Late Devonian

684 and greater connections to nearby basins. In addition, new localities have produced co-

685 occurring, well-preserved articulated vertebrate and invertebrate material, a rarity in the

686 Paleozoic record outside Michigan.

687 There is a definite shift in fish diversity, geologic range, and number between the Middle and 
688 Late Devonian deposits of Michigan. Placoderms, acanthodians, dipnoans, onychodonts and

689 sharks are found in fair numbers in the primarily nearshore settings of the Middle Devonian

690 (Dorr and Eschman, 1970; Fig. 13A). This record includes 16 confirmed genera of fishes from

691201 reported specimens sourced from 11 separate formations (Dorr and Eschman, 1970;

692 personal observation). In contrast, fish fossils from Late Devonian pelagic settings come from

693 just four confirmed genera, all arthrodiran or ptyctodont placoderms, in the Antrim Shale

694 formation (Dorr and Eschman, 1970, Carr and Jackson, 2005; Fig. 13B). Reports from Elliott

695 et al. (2000) indicates that there may be a greater diversity of vertebrates present in the Antrim

696 Shale than what is represented in museum collections (Dorr and Eschman, 1970; personal

697 observation). Even if these reports are confirmed it is still considerably less diverse and

698 abundant than what is observed in Middle Devonian deposits. A similar change is seen in the

699 invertebrate fauna; a thriving reef and nearshore fauna hosting a multitude of life, including

700 crinoids, trilobites, bryozoans, corals, blastoids, brachiopods, cephalopods, gastropods and

701 stromatoporoids in the Middle Devonian is succeeded by scattered fossils of brachiopods and

702 cephalopods further offshore in the Late Devonian (Dorr and Eschman, 1970; Ehlers and

703 Kesling, 1970; Hannibal et al., 1992; Carr pers. comm. 2014).

704 The contrast between the Middle and Late Devonian vertebrate and invertebrate faunas in

705 Michigan is due to differences in collection intensity, rock exposure, and environmental

706 representation. There are at least a dozen well-documented Middle Devonian localities from

707 Michigan that have been the focus of both professional and amateur collectors (Dorr and

708 Eschman, 1970; personal observation). These localities preserve a wide variety of habitats

709 (mostly near-shore, reef habitats) and have a large amount of exposed rock (especially in 
710 limestone quarries) (Ehlers and Kesling, 1970; personal observation). In contrast, the Late

711 Devonian of Michigan is represented by four localities from a single, black shale heavy

712 formation that have comparatively little rock exposed (Ehlers and Kesling, 1970). Furthermore,

713 Ehlers and Kesling (1970) argued that an abundant vertebrate fauna is unlikely to be recovered

714 from the Antrim Shale because of the hardness of the concretions from this formation and the

715 rarity of vertebrate specimens within them. It is therefore unlikely that the small amount of

716 attention Late Devonian localities have received from amateur collectors is the driving factor

717 behind the observed drop in the diversity and abundance of vertebrates. It is notable that the

718 Antrim Shale was deposited in an open water pelagic habitat with little to no benthic community

719 (Gutshick and Sandberg, 1991). None of the localities from the Middle Devonian of Michigan

720 preserve this kind of habitat (Ehlers and Kesling, 1970). This difference in environment between

721 the Middle and Late Devonian deposits is most likely a major factor contributing to the observed

722 shift in the diversity of the vertebrate and invertebrate faunas.

723 Re-examination of Michigan's Devonian fossils sheds some light on biogeographic and

724 dispersal patterns for North American fishes of this age. A complete absence of endemic taxa

725 at the genus level within Michigan suggests that there were few barriers to dispersal with other

726 parts of the mid-continental region of the Old Red Sandstone Continent during the Middle

727 Devonian (Newberry, 1889; Dorr and Eschman, 1970; Denison, 1978; Markus, 1998; Palmer,

728 1999; Warren et al., 2000; Elliott et al., 2000; Thomson and Thomas, 2001; Sepkoski, 2002;

729 Johanson et al., 2007; Carr and Jackson, 2008; Carr and Hlavin, 2010). However, it is possible

730 that the aforementioned lack of taxonomic work and collection effort has resulted in the

731 incorrect attribution of distinct species from Michigan to taxa from the wider region.

732 Regardless, the types of fish found in the Devonian sediments of Michigan are fairly typical 
733 for the eastern United States (Newberry, 1873; Cluff, 1980).

734 Michigan's fish fauna shares characteristics with several similarly-aged faunas from the

735 Middle Devonian of North America. Michigan's Middle Devonian vertebrate fauna is closest in

736 composition to the similarly aged Delaware and Columbus Formations of central Ohio, with

737 which it shares many taxa, including Machaeracanthus, Gyracanthus, Holonema,

738 Macropetalichthys, Protitanichthys, Onychodus, Dunkleosteus, Ptyctodus, and Eczematolepis

739 (Eastman, 1907; Westgate and Fischer, 1933; Wells, 1944; Dorr and Eschman, 1970; Denison,

740 1978; Martin, 2002). This suggests that the parts of Michigan and Ohio that these deposits

741 represent were closely connected during this period of time, yet the preservational mode was

742 quite different. Many of the described fish remains from the Delaware and Columbus limestones

743 are very small and worn, concentrated into bone beds where vertebrate remains are more

744 common than macroscopic invertebrate fossils (Westgate and Fisher, 1933; Wells, 1944). This is

745 very different than Michigan, where fish remains are generally large to medium size pieces of

746 armor or spines that are usually unworn (personal observation). However, Martin (2002)

747 describes the remains of more complete specimens of placoderms (petalichthyids and

748 ptyctodonts) and onychodonts from other, lesser known sections of the Delaware and Columbus

749 limestones, indicating that some beds are more similar to Michigan in preservation and 750 assemblage composition.

751 The Middle Devonian fish fauna of Michigan is also similar to the vertebrate fauna known

752 from the Onondaga Limestone of New York (Eifelian, Upper Ulsterian), which has a similar

753 environment to and is comparable in age to the Dundee Limestone (Brett and Ver Straeten, 1994;

754 Brett et al., 2011). Indeed, the Onondaga Limestone shares all but one of the taxa found in the

755 Dundee Limestone, including Ptyctodus, Machaeracanthus, Onychodus, Eczematolepis, and 
756 Macropetalichthys (Eastman, 1907; Dorr and Eschman, 1970; Denison, 1978). A larger number

757 of vertebrate taxa have been reported from the Onondaga Limestone, although this might be an

758 artifact of the lesser number of outcrops of this age in Michigan and a lack of collecting effort at

759 said outcrops, rather than reflective of real differences in diversity (Eastman, 1907; Dorr and

760 Eschman, 1970; Denison, 1978).

761 The correlation between the vertebrate faunas of Michigan and New York continues into the

762 Givetian (Erian). The rocks of the Traverse Group in Michigan and the Hamilton Group of New

763 York are similar in age and share two vertebrate taxa, Machaeracanthus and Dunkleosteus

764 (Eastman, 1907; Dorr and Eschman, 1970; Denison, 1978; Brett and Ver Straeten, 1994). This is

765 despite an environmental shift that caused major changes in sedimentation, paleoecology, faunas,

766 and basin geometry that occurred in the transition between the Onondaga Limestone and the

767 Hamilton Group (Ver Straeten et al., 1994). This shift had a major effect on the invertebrate

768 fauna of the region, causing extinctions of some of the endemic Onondaga faunas (Ver Straeten

769 et al., 1994). While it is not clear what effect this shift had on the vertebrate fauna of New York,

770 it is evident that a close connection between the fish faunas of Michigan and New York

771 continued from the Eifelian (Ulsterian) into the Givetian (Erian).

772 The documented loss in the amount and diversity of fossil material in the Late Devonian of

773 Michigan makes detailed comparison with other Late Devonian faunas difficult. However, the

774 vertebrate genera found in the Late Devonian of Michigan, D. lafargei, ?T. clarki, ptyctodonts,

775 A. clavatus, and Dunkleosteus, are also found in open ocean sediments of the Late Devonian

776 Cleveland Shale (Newberry, 1889; Winston and Walker, 1956; Dorr and Eschman, 1970;

777 Denison, 1978; Carr and Jackson, 2008). The Cleveland Shale has been the focus of intense

778 collecting efforts for the past 150 years and has outcrops both within a major metropolitan area 
779

780

781

782

783

784

785

786

787

788

789

790

791

792

793

794

795

796

797

798

799

800

and on the path of a major highway, while very little collecting has been conducted in the relatively remote, low abundance, and difficult-to-sample Antrim Shale (Hlavin; 1976). In contrast, the Cleveland Member of the Ohio Shale is a Konservat-Lagerstätten, and is considered one of the most diverse vertebrate faunas from the Devonian (Carr and Jackson, 2008). Therefore, the gap in the diversity and number of fish specimens between the Late Devonian of Michigan and the Late Devonian of Ohio is probably largely the result of the differences in preservation between these sites, along with a lack of organized collection effort in Michigan's Late Devonian sediments by both professionals and amateurs.

A notable occurrence, or non-occurrence, in the Middle Devonian fish fauna of Michigan is a complete lack of antiarch placoderms (Dorr and Eschman, 1970). Additional benthic, nearshore forms, such as gyracanthids and ptyctodonts, are also poorly represented relative to other kinds of fishes (such as arthrodires) in Michigan's sediments. The relative absence of benthic-associated fishes contrasts greatly with the large amount of benthic invertebrate material at vertebrate-bearing localities, which indicates that preservation of the sea floor is not the issue. It is possible that the rarity of antiarchs is purely the product of a lack of collection effort outside of a handful of sites. However, it appears that antiarchs are also uncommon in other Middle Devonian sites that are closely related to deposits of the same age in Michigan (Eastman, 1907; Westgate and Fisher, 1933; Wells, 1944). This is despite the fact that antiarchs have been recovered from nearshore marine and estuarine settings elsewhere, such as the famous marine tetrapod assemblage, Andryevka-2 (Sallan and Coates, 2010;

Friedman and Sallan, 2012).

Another interesting aspect of the vertebrate record from the Middle Devonian of Michigan 
801 is the occurrence of partially articulated vertebrate material preserved alongside invertebrate

802 remains not only in the same formations, but in the same rocks (Fig. 5D). This pattern is

803 consistent in several separate formations and sites. It is rare to find articulated fish remains,

804 rather than ichthyoliths like teeth, directly associated with complete invertebrate remains,

805 especially articulated crinoids, in the Middle Paleozoic (personal observation; Sallan et al.,

806 2011). This direct association can be used to concretely determine which invertebrate taxa

807 lived directly alongside vertebrates, potentially shedding light on the interactions and

808 associations between these groups.

809 Much more fieldwork is required to fully understand the Devonian vertebrate fauna from

810 Michigan. Recent efforts have revealed a surprising number of new occurrences of fishes in

811 geological formations where they were previously considered absent. $P$. rockportensis was

812 once thought to be restricted to the Rockport Quarry Limestone, but has now been

813 documented from the Four Mile Dam Formation and possibly the Alpena Limestone

814 Formation (Dorr and Eschman, 1970; personal observation). Mylostoma sp. was previously

815 only known from an isolated specimen (UMMP 13612) from the Rockport Quarry Limestone,

816 but it is now also known from large numbers of recently collected specimens from the Four

817 Mile Dam Formation and several specimens (BV3, BV6, and BV7) from the Alpena

818 Limestone Formation (Dorr and Eschman, 1970). Additionally, fish fossils had previously

819 never been documented from the Four Mile Dam Formation (personal observation; Dorr and

820 Eschman, 1970). These findings, which are a result of intensified collecting from a handful of

821 the vertebrate-bearing Middle Devonian localities in Michigan, show that these long-neglected

822 localities are still productive. Further collecting at sites that have been ignored for decades 
823 will almost certainly lead to more discoveries. Renewed search efforts will create a less biased

824 understanding of the Late Devonian fish fauna of Michigan, allowing more accurate

825 comparisons to other Late Devonian faunas to be made and the ecology and biogeography of

826 Devonian marine fishes to be more completely known.

827

828

829

830

831

832

833

834

835

836

837

838

839

840

841

842

843

844

845

846

847

848

849

\section{CONCLUSIONS}

Novel information about the ecology, diversity, and number of the fishes from the

Devonian of Michigan has been revealed by new surveys of old material and from new specimens obtained through recent collecting efforts. These include many previously

unrecognized patterns, such as dramatic losses in vertebrate diversity between the Middle and Late Devonian that are likely due to the differences in rock exposure and environmental representation between these time periods. We have also documented strong connections with other North American pelagic faunas, and the exceptional occurrence of partially-articulated fishes preserved alongside benthic invertebrates. These discoveries show that there is still a lot of work to be done in Michigan's vertebrate-bearing Devonian sediments, with implications for our understanding of Devonian fish faunas as a whole.

\section{ACKNOWLEDGEMENTS}

We would like to thank Dr. Michael Gottfried and Laura Abraczinskas for providing crucial data from Michigan State University's fossil collection. We would also like to thank Dr. Robert Carr, for helping to identify fossils, providing information on his work in the Antrim 
850 Shale, and providing insightful reviews on this paper. We would also like to thank Dr. John

851 Long for his comments, suggestions, and providing access to his collection of placoderm

852 literature, which were all crucial in the completion of this paper. We would also like to thank

853 Dr. Jeffrey Wilson for his valuable comments on the manuscript, Dr. Adam Rountrey, for

854 providing access to the University of Michigan's fossil fish collection, Bruce Tobin, for

855 donating crucial specimens used in this study, John Paul Hodnett, for providing key insights on

856 shark specimens, Scott Peters, for helping with the donation of the specimens collected for this

857 study, and Joseph Kchodl, who has been instrumental in pin-pointing the geological affinities

858 of many of the fish fossils and localities used in the data collection for this study. Finally, we

859 would like to thank Dr. Murray Borrello for his encouragement and support.

860

861

862

863

864

865

866

867

868

869

870

871

872

873

874

\section{REFERENCES}

Agassiz, L. 1833-1844. Recherches Sur Les Poissons fossiles [5 volumes]. Neuchátel: Imprimérie de Petitpierre.

Blieck A, Leliévre H. 1995. Palaeozoic vertebrates of northern France and Belgium. Part 1: Heterostraci, Osteostraci, Thelodonti, Placodermi (Devonian). GeoBios 19: 311-317 DOI:10.1016/S0016-6995(95)80132-4.

Boyle JT, Ryan MJ. 2017. New information on Titanichthys (Placodermi: Arthrodira) from the Cleveland Shale (Upper Devonian) of Ohio, USA. Journal of Paleontology 91(2):318-336 DOI:10.1017/jpa.2016.136.

Brett CE, Ver Straeten CA. 1994. Stratigraphy and facies relationships of the Eifelian Onondaga Limestone (Middle Devonian) in western and west central New York 
875

876

877

878

879

880

881

882

883

884

885

886

887

888

889

890

891

892

893

894

895

896

897

State. In: Brett CE, Scatterday J, eds. New York State Geological Association 66th Annual Field Trip Guidebook, 221-269.

Brett CE, Baird GC, Bartholomew AJ, DeSantis MK, Ver Straeten CA. 2011. Sequence stratigraphy and a revised sea-level curve for the Middle Devonian of eastern North America. Palaeogeography, Palaeoclimatology, Palaeoecology 304(1-2):21-53 DOI:10.1016/j.palaeo.2010.10.009.

Briggs LI. 1959. Physical stratigraphy of Lower Middle Devonian rocks in the Michigan Basin. In Sheldon FD, ed. Geology of Mackinac Island and Lower and Middle Devonian south of the straits of Mackinac. Michigan Basin Geological Society Fieldguide, 39-58.

Brusatte SL. 2007. Pennsylvanian (Late Carboniferous) chondrichthyans from the LaSalle Limestone Member (Bond Formation) of Illinois, USA. Neues Jahrbuch für Geologie und Paläontologie-Abhandlungen 244(1):1-8 DOI:10.1127/0077-7749/2007/02440001 .

Carr RK, Jackson GL. 2005. Diplognathus lafargei sp. nov. from the Antrim Shale (Upper Devonian) of the Michigan Basin, Michigan, USA. Revista Brasileira de Paleontologia 8(2):109-116.

Carr RK, Jackson GL. 2008. The vertebrate fauna of the Cleveland Member (Famennian) of the Ohio Shale. In: Guide to the Geology and Paleontology of the Cleveland Member of the Ohio Shale (68th Annual Meeting of the Society of Vertebrate Paleontology, Cleveland, Ohio October 15-18, 2008). Ohio Geological Survey Guidebook 22, 1-17.

Carr RK, Hlavin WJ. 2010. Two new species of Dunkleosteus Lehman, 1956, from the Ohio Shale Formation (USA, Famennian) and the Kettle Point Formation (Canada, 
Upper Devonian), and a cladistic analysis of the Eubrachythoraci (Placodermi,

899 Arthrodira). Zoological Journal of the Linnean Society 159:195-222. DOI:

900 10.1111/j.1096-3642.2009.00578.x.

901

902

903

904

905

906

Case EC. 1931. Arthrodiran remains from the Devonian of Michigan. Contributions from The Museum of Paleontology, University of Michigan 3(9):163-182.

Cluff RM. 1980. Paleoenvironment of the New Albany Shale Group (Devonian-Mississippian) of Illinois. Journal of Sedimentary Research 50(3):767-780 DOI:10.1306/212F7AE02B24-11D7-8648000102C1865D.

Daeschler EB, Cressler WL. 2011. Late Devonian paleontology and paleoenvironments at Red Hill and other fossil sites in the Catskill Formation of north-central Pennsylvania. In: Ruffolo RM, Ciampaglio CN, eds. From the Shield to the Sea: Geological Field Trips from the 2011 Joint Meeting of the GSA Northeastern and North-Central Sections. Boulder: Geological Society of America, 1-16.

Denison RH. 1978. Placodermi. In: Schultze HP, ed. Handbook of Paleoichthyology. Stuttgart: Gustav Fischer Verlag, 2:1-128. .1979. Acanthodii. In: Schultze HP, ed. Handbook of Paleoichthyology. Stuttgart: Gustav Fischer Verlag, 5:1-62.

Derycke C, Cloutier R, Candilier AM. 1995. Palaeozoic vertebrates of northern France and Belgium: Part II. Chondrichthyes, Acanthodii, Actinopterygii (uppermost Silurian to Carboniferous). GeoBios 28(2):343-350. DOI:10.1016/S00166995(95)80136-7.

Dorr JA, Eschman DF. 1970. Geology of Michigan. Ann Arbor: University of Michigan Press. 
921 Downs JP, Criswell KE, Daeschler EB. 2011. Mass mortality of juvenile

922

923

924

925

926

927

928

929

930

931

932

933

934

935

936

937

938

939

940

941

942

943

antiarchs (Bothriolepis sp.) from the Catskill Formation (Upper Devonian, Famennian

Stage), Tioga County, Pennsylvania. Proceedings of the Academy of Natural Sciences of

Philadelphia 161(1):191-203. DOI:10.1635/053.161.0111.

Eastman CR. 1897a. Tamiobatis vetustus; a new form of fossil

skate. American Journal of Science 4:85-90.

.1897b. On the characters of Macropetalichthys. The American

Naturalist 31(366):493-499.

1906. Structure and relations of Mylostoma. Bulletin of the Museum of Comparative

Zoology 50(1):1-29.

1907. Devonic fishes of the New York formations. New York

State Museum, Memoir 10. Albany: New York State Education

Department.

.1908. Devonian Fishes of Iowa. Des Moines: Iowa Geological Survey Annual Report.

Ehlers GM, Kesling RV. 1970. Devonian strata of Alpena and Presque Isle Counties, Michigan. Michigan Basin Geological Society Guidebook, Geological Society of America, North-Central Section Meeting.

Elliott DK, Johnson HG, Cloutier R, Carr RK, Daeschler EB. 2000.

Middle and Late Devonian vertebrates of the western Old Red Sandstone

Continent. Courier-Forschungsinstitut Senckenberg 223:291-308.

Elliott DK, Irmis RB, Hansen MC, Olson TJ. 2004. Chondrichthyans from the Pennsylvanian (Desmoinesian) Naco Formation of central Arizona. Journal of Vertebrate Paleontology 24(2):268-280. DOI:10.1671/1978. 
944 Friedman M, Sallan LC. 2012. Five hundred million years of extinction and

945

946

947

948

949

950

951

952

953

954

955

956

957

958

959

960

961

962

963

964

965

966

recovery: a Phanerozoic survey of large-scale diversity patterns in fishes. Paleontology 55(4):707-742 DOI:10.1111/j.1475-4983.2012.01165.x.

Gardiner BG. 1984. The relationship of Placoderms. Journal of Vertebrate Paleontology 4(3):379-395. DOI:10.1080/02724634.1984.10012017.

Gradstein FM, Ogg JG, Smith AG. 2004. A Geologic Time Scale 2004. Cambridge: Cambridge University Press.

Gutschick RC, Sandberg CA. 1991. Late Devonian history of the Michigan Basin. In: Catacosinos PA, Daniels PA Jr., eds. Early sedimentary evolution of the Michigan Basin, Geological Society of America Special Paper 256. Boulder: Geological Society of America, 181-200.

Hannibal JT, Carr RK, Frye CJ. 1992. “Tintenflecken” from the Michigan Basin: preservation, ontogeny, and variation of aptychi found in Upper Devonian rocks at Paxton Michigan. Geological Society of America, Abstracts with Programs 24(7):A224A225.

Hlavin WJ. 1976. Biostratigraphy of the Late Devonian black shales on the cratonal margin of the Appalachian Geosyncline. D. Phil. Thesis, Boston University.

Hussakof L. 1913. Descriptions of four new Palaeozoic fishes from North America. Bulletin of the American Museum of Natural History 32(11):245-250.

Itano WM, Houck KJ, Lockley MG. 2003. Ctenacanthus and other chondrichthyan spines and denticles from the Minturn Formation (Pennsylvanian) of Colorado. Journal of Paleontology 77(3):524-535. DOI:10.1666/00223360(2003)077<0524:CAOCSA $>2.0 . \mathrm{CO} ; 2$. 
967 Janvier P. 2003. Early Vertebrates. Oxford: Clarendon Press.

968 Johanson Z, Long J, Talent J, Janvier P, James W. 2007. New

969 Onychodontiform (Osteichthyes; Sarcopterygii) from the Lower Devonian of Victoria,

970 Australia. Journal of Paleontology 81(5): 1031-1043. DOI:10.1666/pleo05-023.1.

971 Kiessling W, Simpson C, Foote M. 2010. Reefs as cradles of evolution and

972 sources of biodiversity in the Phanerozoic. Science 327(5962):196-198. DOI:

$973 \quad 10.1126 /$ science.1182241.

974 Lehman JP. 1956. Les arthrodires du Dévonien supérieur du Tafilalet (sud marocain). Notes 975 et Mémoires. Service Géologique du Maroc 129:11-70.

976 Lilienthal RT. 1978. Stratigraphic cross-sections of the Michigan Basin. Geological

977 Survey Division, Michigan Department of Natural Resources, Report of Investigation

978

19. Available at https://dspace.nmc.edu/handle/11045/24106 (accessed 10 August 2018)

979

Long JA. 1995. The Rise of Fishes: 500 Million Years of Evolution. Baltimore: Johns Hopkins 980 University Press.

981 .2011. The Rise of Fishes: 500 Million Years of Evolution, 2nd edition. Baltimore:

982 Johns Hopkins University Press.

983

984

985

986

987

988 989

Maisey JG. 1982. Studies on the Paleozoic selachian genus Ctenacanthus Agassiz:

No. 2, Bythiacanthus St. John and Worthen, Amelacanthus, new genus, Eunemacanthus

St. John and Worthen, Sphenacanthus Agassiz, and Wodnika Münster. American Museum novitates 2722:1-24.

.1983. Some Pennsylvanian chondrichthyan spines from Nebraska. Transactions of the Nebraska Academy of Sciences 11:81-84.

Martin RL. 2002. Taxonomic Revision and Paleoecology of Middle Devonian (Eifelian) 
Fishes of the Onondaga, Columbus and Delaware Limestones of the eastern United

991 States. D. Phil. Thesis, West Virginia University.

992 993 994 995 996 997 998 999 1000 1001

Miles RS. 1966. Protitanichthys and some other coccosteomorph arthrodires from the Devonian of North America. Kungliga Svenska Vetenskapsakademien Handlingar 10(4): $1-45$.

.1971. The Holonematidae (placoderm fishes), a review based on new specimens of Holonema from the Upper Devonian of Western Australia. Philosophical Transactions of the Royal Society of London. Series B, Biological Sciences 263(849):101-234. .1977. Dipnoan (lungfish) skulls and the relationships of the group: a study based on new species from the Devonian of Australia. Zoological Journal of the Linnean Society 61:1-328.

Miller SA. 1892. First appendix to North American geology and palaeontology for use of amateurs, students and scientists. Cincinnati: Western Methodist Book Concern, 665718.

Newberry JS. 1868. On some remarkable fossil fishes discovered by Rev. H. Herzer in the black shale (Devonian) at Delaware, Ohio. In: Lovering J, ed. Proceedings of the American Association for the Advancement of Science, 17th Meeting held at Burlington, Vermont, August, 1867. Boston: F. B. Dakin, Printer, 146-147. .1873. Geological Structure Ohio Devonian system. Geological Survey of Ohio 1:140-167. .1883. Some interesting remains of fossil fishes, recently discovered. Transactions of the New York Academy of Science 2:144-147. .1885. Descriptions of some gigantic placoderm fishes recently discovered in the 
1013 Devonian of Ohio. Transactions of the New York Academy of Sciences 5:25-28.

1014 1889. Paleozoic fishes of North America, Volume 16 of Monographs of the United

1015 States Geological Survey. Washington: U.S. Government Printing Office.

1016 1897. New species and a new genus of American Paleozoic fishes together with notes

1017 on the genera Oracanthus, Dactylodus, Polyrhizodus, Sandalodus, and Deltodus.

1018 Transactions of the New York Academy of Sciences 16:282-304.

1019 Norwood JG, Owen DD. 1846. Description of a new fossil fish, from the Palaeozoic

1020 rocks of Indiana. American Journal of Science and Arts 1(3):367-371.

1021 Palmer D. 1999. The Marshall Illustrated Encyclopedia of Dinosaurs and

1022 Prehistoric Animals. A Comprehensive, Colour Guide to over 500 Species. London:

$1023 \quad$ Marshall Publishing.

1024 Pander CH. 1858. Die Ctenodipterinen des devonischen systems. St. Petersburg:

1025 Buchdruckerei Der Kaiserlichen Akademie Der Wissenschaften.

1026 Pohl ER. 1930. The Middle Devonian Traverse Group of rocks in Michigan, a summary of 1027 existing knowledge. Proceedings of the U.S. National Museum 76(14):1-38.

1028 Roen JB. 1984. Geology of the Devonian black shales of the Appalachian Basin. Organic

1029 Geochemistry 5(4):241-254. DOI:10.1016/0146-6380(84)90011-1.

1030 Rücklin M. 2010. A new Frasnian placoderm assemblage from the eastern Anti-Atlas,

$1031 \quad$ Morocco, and its biogeographical implications. Palaeoworld 19:87-93. DOI

$1032 \quad$ 10.1016/j.palwor.2009.11.002.

1033 Sandberg CA, Morrow JR, Ziegler W. 2002. Late Devonian sea-level changes, catastrophic 1034 events, and mass extinctions. In: Koeberl C, MacLeod KG, eds. Catastrophic Events and 1035 Mass Extinctions: Impacts and Beyond. Boulder: Geological Society of America Special 
Paper 356, 473-487.

1037 Sallan LC, Coates MI. 2010. End-Devonian extinction and a bottleneck in the

1038

1039 early evolution of modern jawed vertebrates. Proceedings of the National Academy of Sciences 107(22):10131-10135. DOI:10.1073/pnas.0914000107.

1041

1042

Sallan LC, Kammer TW, Ausich WI, Cook LA. 2011. Persistent predator-prey dynamics revealed by mass extinction. Proceedings of the National Academy of Sciences 108(20):8335-8338 DOI:10.1073/pnas.1100631108.

1044

Schultze HP. 1982. A dipterid dipnoan from the Devonian of Michigan, U.S.A. Journal of Vertebrate Paleontology 2(2):155-162 DOI:10.1080/02724634.1982.10011926.

Sepkoski JJ. 2002. A compendium of fossil marine animal genera. Bulletin of American Paleontology 363:1-560.

Stevens MS. 1964. Thoracic armor of a new arthrodire (Holonema) from the Devonian of Presque Isle County, Michigan. Papers of the Michigan Academy of Science, Arts, and Letters 49:163-175.

St. John O, Worthen AH. 1875. Descriptions of fossil fishes. Geological Survey of Illinois

1051 6(2):245-488.

Swezey C. 2002. Regional stratigraphy and petroleum systems of the Appalachian Basin, North America. U.S. Department of the Interior, U.S. Geological Survey, Geologic Investigations Series: Map I-2768. Available at https://pubs.usgs.gov/imap/i-2768/ (accessed 10 August 2018)

Thomson KS, Thomas B. 2001. On the status of species of Bothriolepis 
1059 Trinajstic K, Long JA. 2009. A new genus and species of Ptyctodont (Placodermi) from

1060 the Late Devonian Gneudna Formation, Western Australia, and an analysis of Ptyctodont

1061 phylogeny. Geological Magazine 146(5):743-760 DOI:10.1017/S001675680900644X.

1062 Turner S, Burrow CJ, Warren A. 2005. Gyracanthides hawkinsi sp.

1063 nov. (Acanthodii, Gyracanthidae) from the Lower Carboniferous of Queensland,

1064 Australia, with a review of gyracanthid taxa. Palaeontology 48(5):963-1006 DOI:

$1065 \quad 10.1111 / \mathrm{j} .1475-4983.2005 .00479 . x$.

1066 Ver Straeten CA, Griffing DH, Brett CE. 1994. The lower part of the

1067 Middle Devonian Marcellus “Shale," central to western New York State: stratigraphy and

1068 depositional history. In: Brett CE, Scatterday, J, eds. New York State Geological

1069 Association, 66th Annual Meeting Guidebook, 270-321.

1070 Warren A, Currie BP, Burrow C, Turner S. 2000. A Redescription and

$107 \mathbf{b}$ Reinterpretation of Gyracanthides murrayi (Acanthodii, Gyracanthidae) from the Lower

1072 Carboniferous of the Mansfield Basin, Victoria, Australia. Journal of Vertebrate

1073 Paleontology 20(2):225-242 DOI:10.1671/02724634(2000)020 [0225:ARAROG]

$1074 \quad 2.0 . \mathrm{CO} ; 2$

1075 Wellburn ED. 1901. VI.- On the Fish Fauna of the Millstone Grits of Great Britain. Geological

1076 Magazine 8(5):216-222. DOI:10.1017/S0016756800156365.

1077 Wells JW. 1944. Middle Devonian bone beds of Ohio. Bulletin of the Geological Society of 1078 America 55:273-302 DOI:10.1130/GSAB-55-273.

1079 Westgate LG, Fischer RP. 1933. Bone beds and crinoidal sands of the Delaware Limestone

$1080 \quad$ of central Ohio. Bulletin of the Geological Society of America 44:1161-1172. DOI:

$1081 \quad$ 10.1130/GSAB-44-1161. 
1082 Williams ME. 1998. A new specimen of Tamiobatis vetustus (Chondrichthyes,

1083 Ctenacanthoidea) from the late Devonian Cleveland Shale of Ohio. Journal of Vertebrate

1084 Paleontology 18(2):251-260 DOI:10.1080/02724634.1998.10011054.

1085

1086

1087

1088

1089

1090

1091

1092

1093

1094

Sinclair GW, Walker DR. 1956. Redescription of Aspidichthys: Arthrodira, Devonian. Ohio Journal of Science 56(3):135-137.

Woodward AS. 1906. On a Carboniferous fish fauna from the Mansfield District, Victoria. Memoirs of the National Museum, Melbourne 1:1-32.

Zangerl R. 1981. Chondrichthyes I: Paleozoic Elasmobranchii. New York: Lubrecht \& Cramer Ltd.

Zhu YA, Zhu M. 2013. A redescription of Kiangyousteus yohii (Arthrodira: Eubrachythoraci) from the Middle Devonian of China, with remarks on the systematics of the Eubrachythoraci. Zoological Journal of the Linnean Society 169:798-819 DOI:10.1111/zoj.12089. 
1095

1096

1097

1098

1099

1100

1101

1102

1103

1104

1105

1106

1107

1108

1109

1110

1111

1112

1113

1114

1115

1116

1117

1118

\section{Figure Captions}

Figure 1: Stratigraphy of the Devonian deposits of the northern part of the Lower Peninsula of Michigan. Figure modified from Elliott et al. (2000), Figure 3.

Figure 2: Chart showing the correlation between international and North American Devonian stage names. Figure modified from Swezey (2002). U.S. Geological Survey.

Figure 3: Vertebrate remains from the Dundee Limestone Formation. (A), a large tooth from $O$. sigmoides, from the Dundee Limestone of London Township, Monroe County, UMMP 22006. Scale bar equals $1 \mathrm{~cm}$. (B), a spinal and anterior ventrolateral plate from ?Macropetalichthys sp. (previously identified as Arctolepis sp.), from the Dundee Limestone near Trenton, UMMP 14320. Abbreviations: Sp, spinal; Spi, spines of the spinal plate; Avl, anterior ventrolateral. Scale bar equals $1 \mathrm{~cm}$.

Figure 4: Vertebrate remains from the Rockport Quarry Limestone Formation. (A), a partial skull roof from Holonema sp., from the Rockport Quarry Limestone at the abandoned Kelly Island Limestone Quarry at Rockport State Park, Alpena County, UMMP 12991.

Abbreviations: Nu, Nuchal; PNu, Paranuchal; C, Central Plate. Scale bar equals $2 \mathrm{~cm} .(\mathrm{B})$, The remains of an unidentified placoderm from the Rockport Quarry Limestone at the abandoned Kelly Island Limestone Quarry at Rockport State Park, Alpena County, 7M, Michigan History Museum. Scale bar equals $1 \mathrm{~cm}$. (C), an incomplete right anterior ventrolateral from Dunkleosteus sp., from the from the Rockport Quarry Limestone of Rockport Quarry, Alpena County, UMMP 16156. Scale bar equals $2 \mathrm{~cm}$. (D), a small spine from ?Tamiobatis sp. (previously identified as Ctenacanthus sp.) from the Rockport Quarry Limestone at the abandoned Kelly Island Limestone Quarry at Rockport State Park, Alpena County, UMMP 13147. Scale bar equals $1 \mathrm{~cm}$. 
1119 Figure 5: Vertebrate remains from the Four Mile Dam Formation. (A), a broken spine from an

1120 unidentified acanthodian, from the Four Mile Dam Formation of the Betsie Bay Rockpiles,

1121 Elberta, Benzie County, JS 121, Michigan History Museum. Scale bar equals 0.5 cm. (B), a

1122 flattened specimen of a trunk shield from ?Mylostoma sp., from the Four Mile Dam Formation

1123 of the Betsie Bay Rockpiles, Elberta, Benzie County, 21M. Abbreviations: MD, Median

1124 dorsal; ADL, Anterior dorsolateral; Nu, Nuchal. Scale bar equals $1 \mathrm{~cm}$. (C), a partial armor

1125 plate from an unidentified placoderm, from the Four Mile Dam Formation of the Betsie Bay

1126 Rockpiles, Elberta, Benzie County, JS 4, Michigan History Museum. Scale bar equals $1 \mathrm{~cm}$.

1127 (D), a piece of limestone containing both crinoid heads and an armor plate from ?Mylostoma

1128 sp. from the Four Mile Dam Formation of the Betsie Bay Rockpiles, Elberta, Benzie County,

1129 9M, Michigan History Museum. This specimen is an example of the association between

1130 vertebrates and invertebrates in the Middle Devonian deposits of Michigan. The solid arrow

1131 indicates the armor plate and the dashed arrow indicates a crinoid head. Scale bar equals $1 \mathrm{~cm}$.

1132 Figure 6: Specimens of Protitanichthys rockportensis, an arthrodire that is common in the

1133 Middle Devonian sediments of Michigan. (A), a photograph of an impression of the head of the

1134 holotype, from the Rockport Quarry Limestone at the abandoned Kelly Island Limestone

1135 Quarry at Rockport State Park, Alpena County, UMMP 12980. Scale bar equals 2 cm. (B), a

1136 specimen drawing of UMMP 12980 (redrawn and modified from Case (1931: Figure 1).

1137 Dotted lines represent missing plate boundaries and dashed lines represent sensory grooves.

1138 (C), an incomplete nuchal and left paranuchal plate, from the Rockport Quarry Limestone at

1139 the abandoned Kelly Island Limestone Quarry at Rockport State Park, Alpena County, UMMP

1140 2981. Scale bar equals $1 \mathrm{~cm}$. (D), a partial headshield, most likely from a juvenile, from the

1141 Rockport Quarry Limestone at the abandoned Kelly Island Limestone Quarry at Rockport State 
1142 Park, Alpena County, 4M, Michigan History Museum. Scale bar equals $1 \mathrm{~cm}$.

1143 Figure 7: An inferognathal from the Late Devonian arthrodire ?Trachosteus clarki from the

1144 Antrim Shale. Specimen recovered $1.6 \mathrm{~km}$ north of Norwood, MI. UMMP 18206. Scale bar

1145 equals $1 \mathrm{~cm}$.

1146 Figure 8: Newly discovered specimens of ?Macropetalichthys sp. (A) a partially complete

1147 headshield from ?Macropetalichthys sp. Specimen found in the Four Mile Dam Formation of

1148 the Betsie Bay Rockpiles, Elberta, Benzie County. Abbreviations: Hd, Head Shield

1149 (incomplete), Un, Unidentified Armor Plate, R, Rostral Plate?. Scale bar equals 2 cm. 32M,

1150 Michigan History Museum. (B) crushed and partially articulated pieces of armor from the

1151 anterior portion of the headshield of ?Macropetalichthys sp.. Specimen found in the Alpena

1152 Limestone Formation at the Besser Museum Fossil Park, Alpena. BV 4, Michigan History

1153 Museum. Abbreviations: PrO, Preorbital; R, Rostral. Scale bar equals $1 \mathrm{~cm}$.

1154 Figure 9: An incomplete armor plate from Eczematolepis sp. Specimen from the Genshaw

1155 Formation. Found near Posen, MI. UMMP 4169. Scale bar equals $1 \mathrm{~cm}$.

1156 Figure 10: A supragnathal plate from an unknown ptyctodont from the Traverse Group.

1157 Specimen recovered from an unknown locality referred to as "Locality 650 of the Winchell

1158 Survey”, in Alpena, Alpena County, MI. UMMP 14374. Scale bar equals $1 \mathrm{~cm}$.

1159 Figure 11: Specimens of the acanthodian Machaeracanthus sp. (A), a large spine from

1160 Machaeracanthus sp., from the Dundee Limestone of London Township, Monroe County,

1161 UMMP 3521. Scale bar equals $1 \mathrm{~cm}$. (B), a spine from ?Machaeracanthus sp. (originally

1162 identified as A. gracillimus), from the Rockport Quarry Limestone at the abandoned Kelly

1163 Island Limestone Quarry at Rockport State Park, Alpena County, UMMP 13047. Scale bar 1164 equals $1 \mathrm{~cm}$. 
1165 Figure 12: The skull of Chirodipterus onawayensis. Specimen recovered from from the Newton

1166 Creek Limestone of Onaway Stone Quarry, north of Onaway, Presque Isle County. Specimen

1167 photo from Schultze (1982), Figure 2, modified and reprinted with permission of Taylor and

1168 Francis Ltd, http://www.tandfonline.com. This specimen is reported to be unnumbered at the

1169 Great Lakes Area Paleontological Museum, but is missing. Scale bar equals $1 \mathrm{~cm}$.

1170 Figure 13: A representation of fish faunas from the Devonian of Michigan. Animals not to

1171 scale. Drawing by L.S. (A) The vertebrate fauna from the Middle Devonian of Michigan. (1)

1172 Acondylacanthus (Chondrichthyes); (2), Dinomylostoma (Arthrodira; 'Placodermi'); (3),

1173 Chirodipterus (Dipnoi; Sarcopterygii); (4), Dunkleosteus (Arthrodira; 'Placodermi'); (5),

1174 Onychodus (Onychodontida; Sarcopterygii); (6), Mylostoma (Arthrodira; 'Placodermi'); (7),

1175 Protitianichthys (Arthrodira; 'Placodermi'); (8), Oracanthus (Acanthodida; 'Acanthodii'); (9),

1176 Machaeracanthus (Ischnacanthida; 'Acanthodii'); (10), Gyracanthus (Gyracanthida;

1177 'Acanthodii'); (11), Eczematolepis (Ptyctodontida; 'Placodermi'); (12), Holonema

1178 (Arthrodira; 'Placodermi'). (B) The vertebrate fauna from the Late Devonian of Michigan.

1179 (13) Aspidichthys (Arthrodira; 'Placodermi'); (14), Trachosteus (Arthrodira: 'Placodermi');

1180 (15), Diplognathus (Arthrodira; 'Placodermi'); (16), Ptyctodontida indet. ('Placodermi'). 


\section{Figure 1}

Stratigraphy of the Devonian deposits of the northern part of the Lower Peninsula of Michigan.

Figure modified from Elliott et al. (2000), Figure 3. 


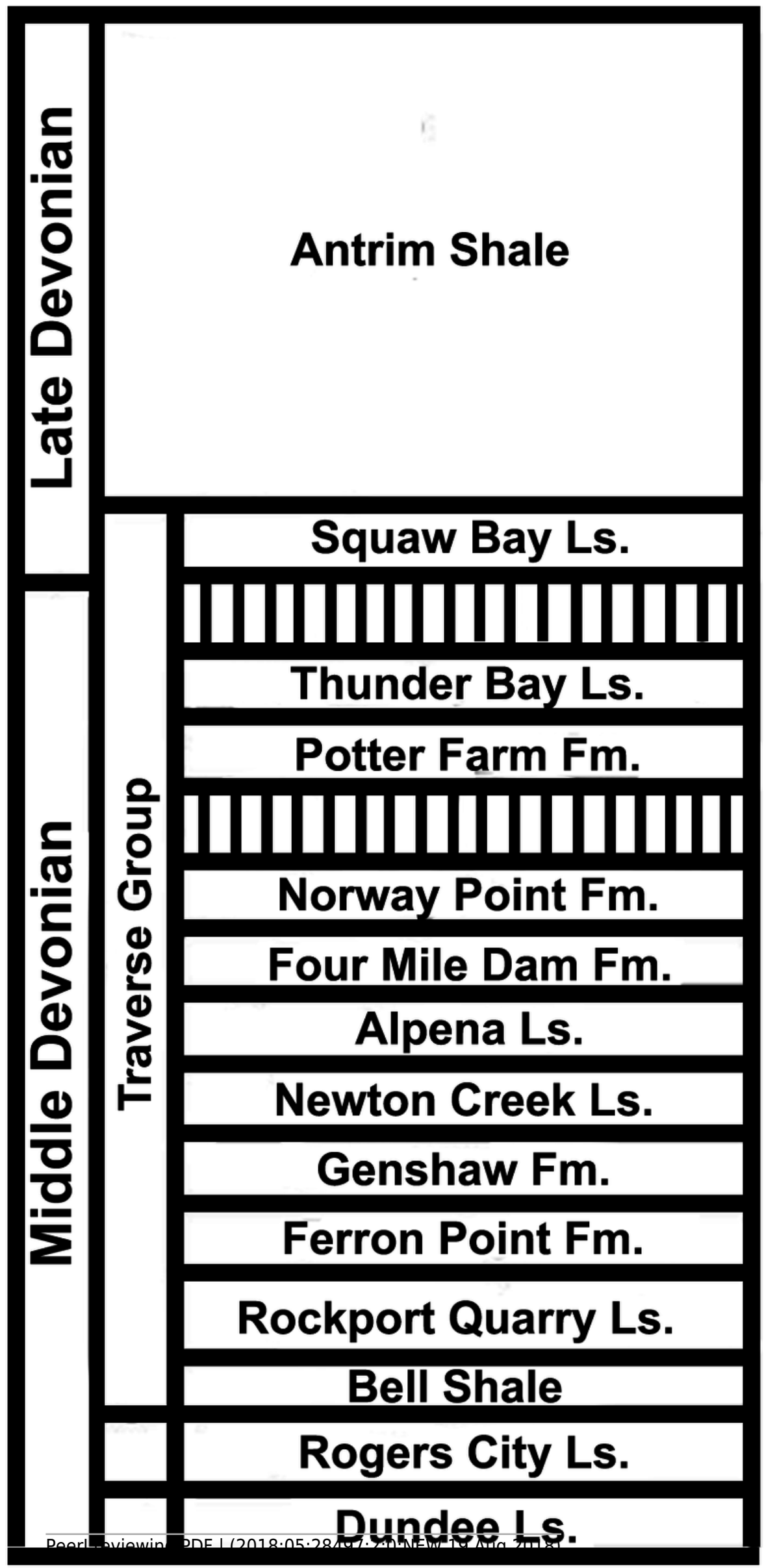


Figure 2

Chart showing the correlation between international and North American Devonian stage names.

Figure modified from Swezey (2002). U.S. Geological Survey. 


\begin{tabular}{|c|c|c|c|}
\hline \multirow{7}{*}{ 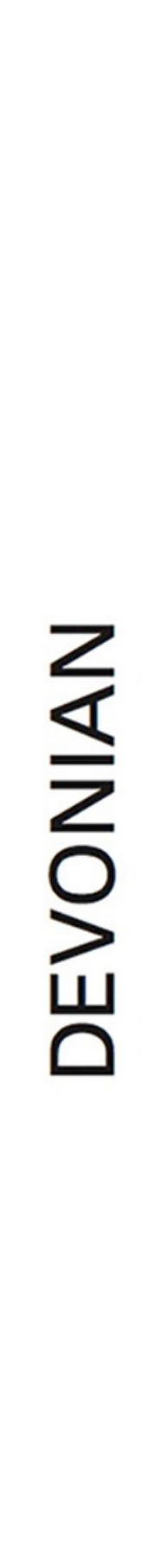 } & \multirow{2}{*}{$\begin{array}{l}\frac{1}{0} \\
\frac{0}{2}\end{array}$} & Famennian & Chautauquan \\
\hline & & Frasnian & Senecan \\
\hline & $\frac{0}{0}$ & Givetian & Erian \\
\hline & $\dot{\Sigma}$ & Eifelian & \\
\hline & & Emsian & \\
\hline & $\overline{(}$ & Pragian & Ulsterian \\
\hline & ב & $\begin{array}{l}\text { Lochkovian } \\
\text { (Gedinnian) }\end{array}$ & \\
\hline
\end{tabular}




\section{Figure 3}

Vertebrate remains from the Dundee Limestone Formation.

(A), a large tooth from O. sigmoides,from the Dundee Limestone of London Township, Monroe County, UMMP 22006. Scale bar equals $1 \mathrm{~cm}$. (B), a spinal and anterior ventrolateral plate from ?Macropetalichthyssp. (previously identified as Arctolepis sp.),from the Dundee Limestone near Trenton, UMMP 14320. Abbreviations: Sp, spinal; Spi, spines of the spinal plate; Avl,anterior ventrolateral. Scale bar equals $1 \mathrm{~cm}$.
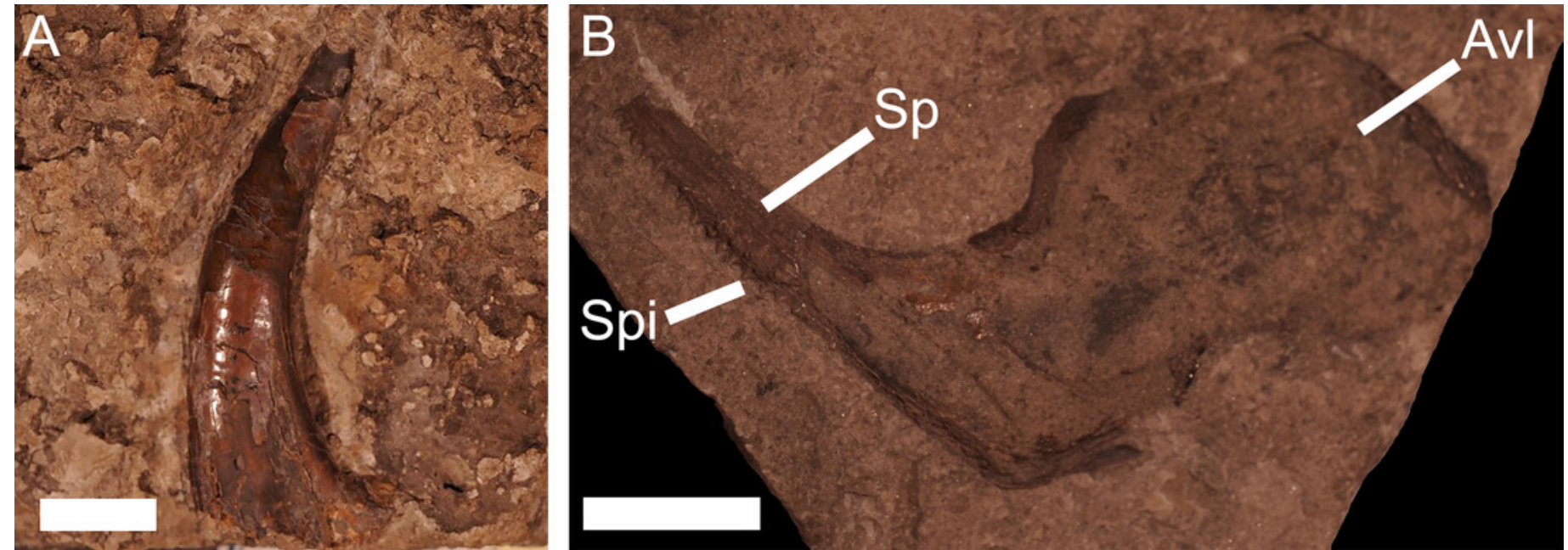


\section{Figure 4}

Vertebrate remains from the Rockport Quarry Limestone Formation.

(A), a partial skull roof from Holonema sp., from the Rockport Quarry Limestone at the abandoned Kelly Island Limestone Quarry at Rockport State Park, Alpena County, UMMP 12991. Abbreviations: Nu, Nuchal; PNu, Paranuchal; C, Central Plate. Scale bar equals $2 \mathrm{~cm}$. (B), The remains of an unidentified placoderm from the Rockport Quarry Limestone at the abandoned Kelly Island Limestone Quarry at Rockport State Park, Alpena County, 7M, Michigan History Museum. Scale bar equals $1 \mathrm{~cm}$. (C), an incomplete right anterior ventrolateral from Dunkleosteus sp.,from the Rockport Quarry Limestone of Rockport Quarry, Alpena County, UMMP 16156. Scale bar equals $2 \mathrm{~cm}$. (D), a small spine from ?Tamiobatissp. (previously identified as Ctenacanthus sp.)from the Rockport Quarry Limestone at the abandoned Kelly Island Limestone Quarry at Rockport State Park, Alpena County, UMMP 13147. Scale bar equals $1 \mathrm{~cm}$. 

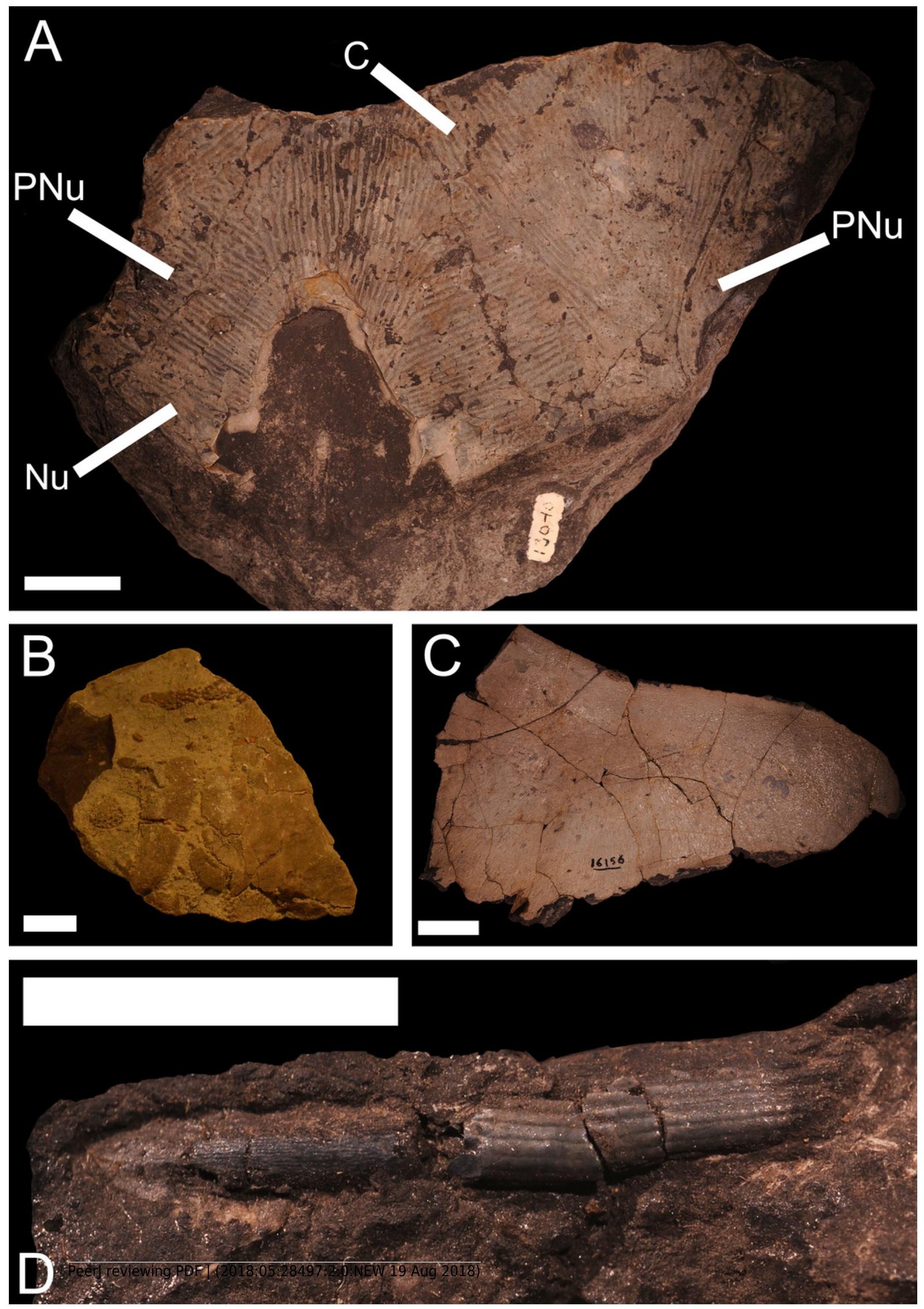


\section{Figure 5}

Vertebrate remains from the Four Mile Dam Formation.

(A), a broken spine froman unidentified acanthodian, from the Four Mile Dam Formation of the Betsie Bay Rockpiles, Elberta, Benzie County, JS 121, Michigan History Museum. Scale bar equals $0.5 \mathrm{~cm}$. (B), a flattened specimen of a trunk shield from ?Mylostoma sp.,from the Four Mile Dam Formation of the Betsie Bay Rockpiles, Elberta, Benzie County, 21M. Abbreviations:

MD, Median dorsal; ADL,Anterior dorsolateral; Nu, Nuchal.Scale bar equals $1 \mathrm{~cm}$. (C), a partial armor plate from an unidentified placoderm, from the Four Mile Dam Formation of the Betsie Bay Rockpiles, Elberta, Benzie County, JS 4, Michigan History Museum. Scale bar equals $1 \mathrm{~cm}$. (D), a piece of limestone containing both crinoid heads and an armor plate from ?Mylostoma sp.from the Four Mile Dam Formation of the Betsie Bay Rockpiles, Elberta, Benzie County, 9M, Michigan History Museum. This specimen is an example of the association between vertebrates and invertebrates in the Middle Devonian deposits of Michigan. The solid arrow indicates the armor plate and the dashed arrow indicates a crinoid calyx. Scale bar equals 1 $\mathrm{cm}$. 

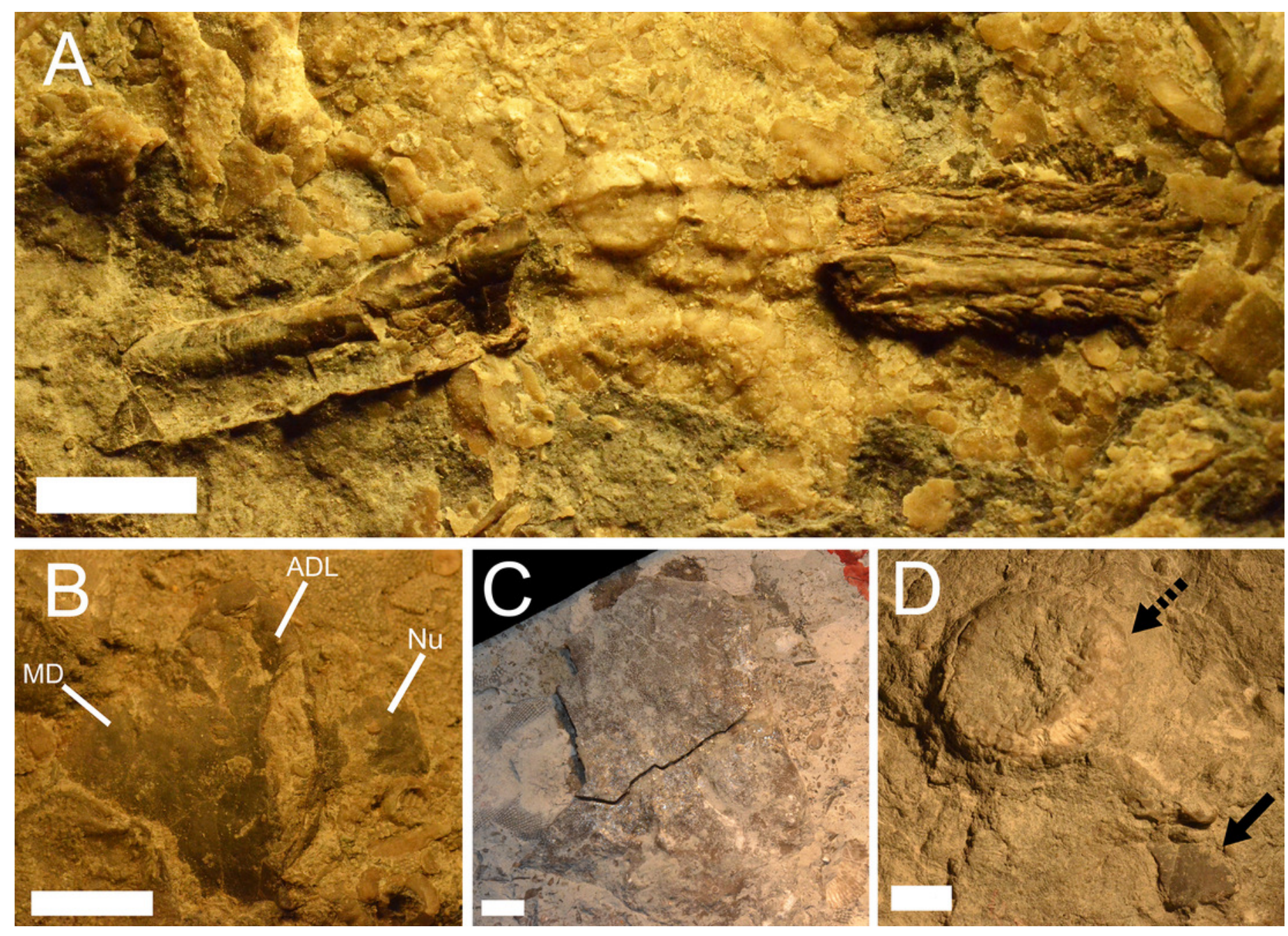


\section{Figure 6}

Specimens of Protitanichthys rockportensis, an arthrodire that is common in the Middle Devonian sediments of Michigan.

(A), a photograph of an impression of the head of the holotype, from the Rockport Quarry Limestone at the abandoned Kelly Island Limestone Quarry at Rockport State Park, Alpena County, UMMP 12980. Scale bar equals $2 \mathrm{~cm}$. (B), a specimen drawing of UMMP 12980 (redrawn and modified from Case (1931: Figure 1). Dotted lines represent missing plate boundaries and dashed lines represent sensory grooves. (C), an incomplete nuchal and left paranuchal plate, from the Rockport Quarry Limestone at the abandoned Kelly Island Limestone Quarry at Rockport State Park, Alpena County, UMMP 2981.Scale bar equals $1 \mathrm{~cm}$. (D), a partial headshield, most likely from a juvenile, from the Rockport Quarry Limestone at the abandoned Kelly Island Limestone Quarry at Rockport State Park, Alpena County, 4M, Michigan History Museum. Scale bar equals $1 \mathrm{~cm}$. 

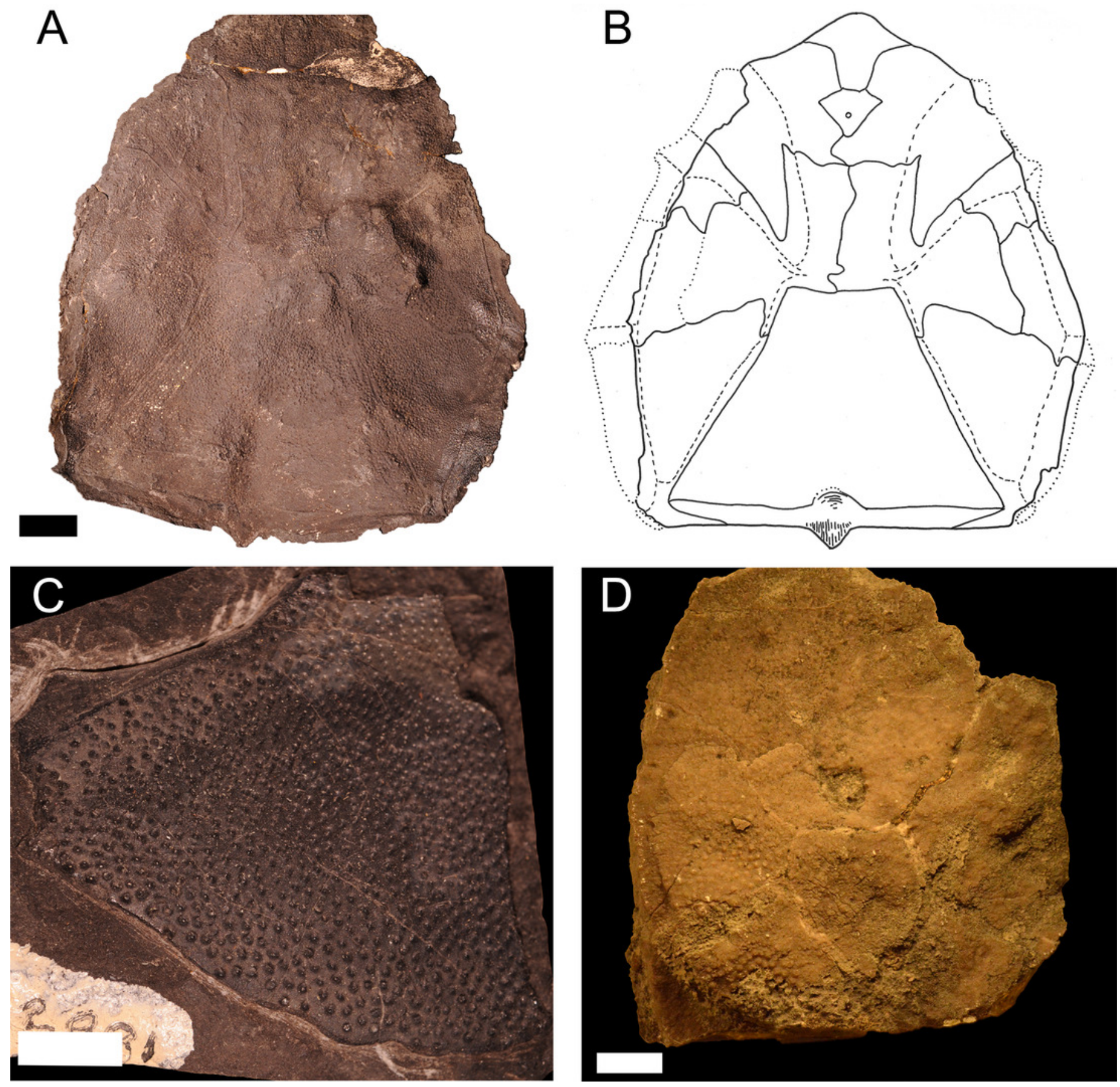


\section{Figure 7}

An inferognathal from the Late Devonian arthrodire ?Trachosteus clarki from the Antrim Shale.

Specimen recovered $1.6 \mathrm{~km}$ north of Norwood, MI. UMMP 18206. Scale bar equals $1 \mathrm{~cm}$.

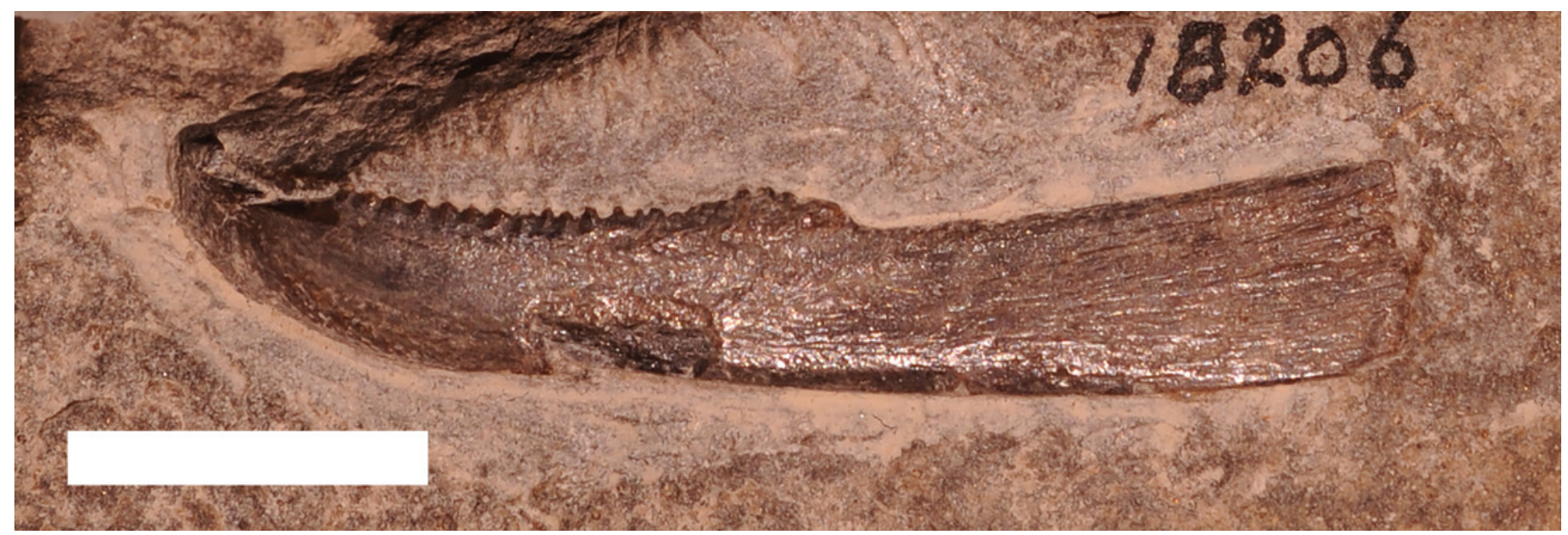




\section{Figure 8}

Newly discovered specimens of ?Macropetalichthys sp.

(A) a partially complete headshield from ?Macropetalichthyssp. Specimen found in the Four Mile Dam Formation of the Betsie Bay Rockpiles, Elberta, Benzie County. Abbreviations: Hd, Head Shield (incomplete), Un, Unidentified Armor Plate, R, Rostral Plate?. Scale bar equals 2 $\mathrm{cm}$. 32M, Michigan History Museum. (B) crushed and partially articulated pieces of armor from the anterior portion of the headshield of ?Macropetalichthys sp.. Specimen found in the Alpena Limestone Formation at the Besser Museum Fossil Park, Alpena. BV 4, Michigan History Museum. Abbreviations: PrO, Preorbital; R, Rostral. Scale bar equals $1 \mathrm{~cm}$.
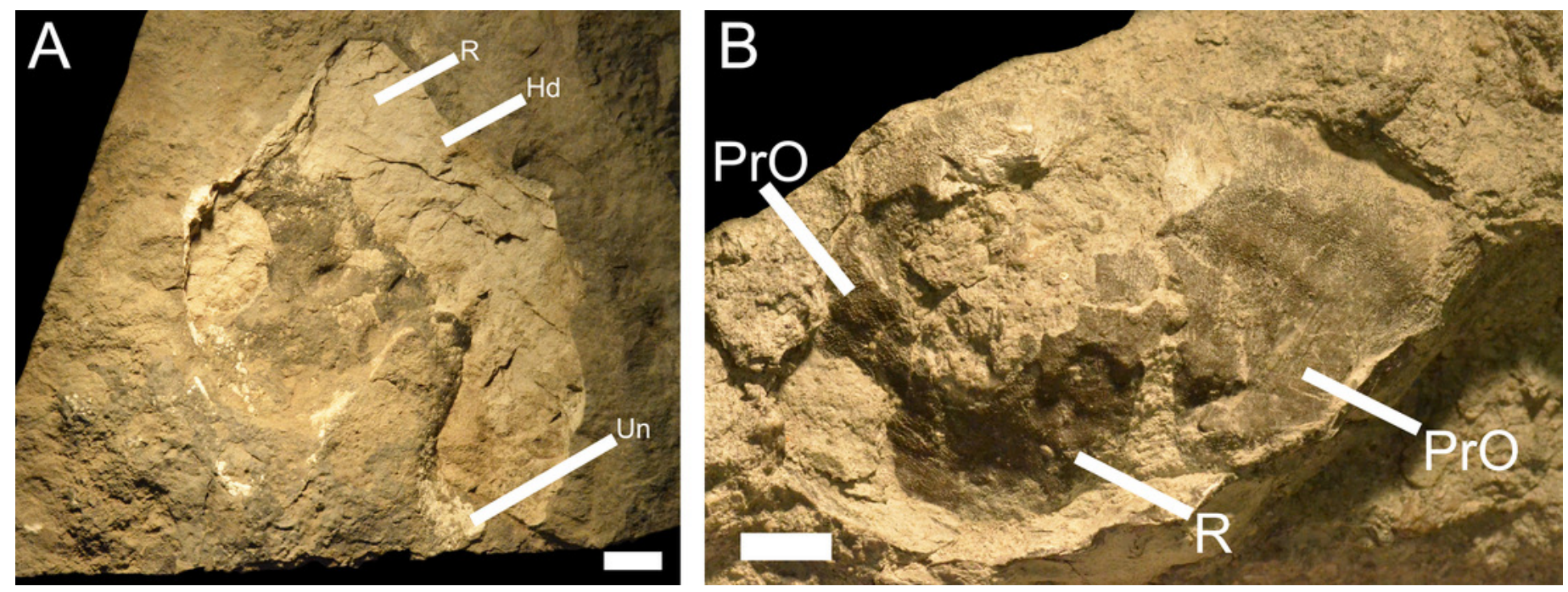
Figure 9

An incomplete armor plate from Eczematolepis sp.

Specimen from the Genshaw Formation. Found near Posen, MI. UMMP 4169. Scale bar equals $1 \mathrm{~cm}$. 


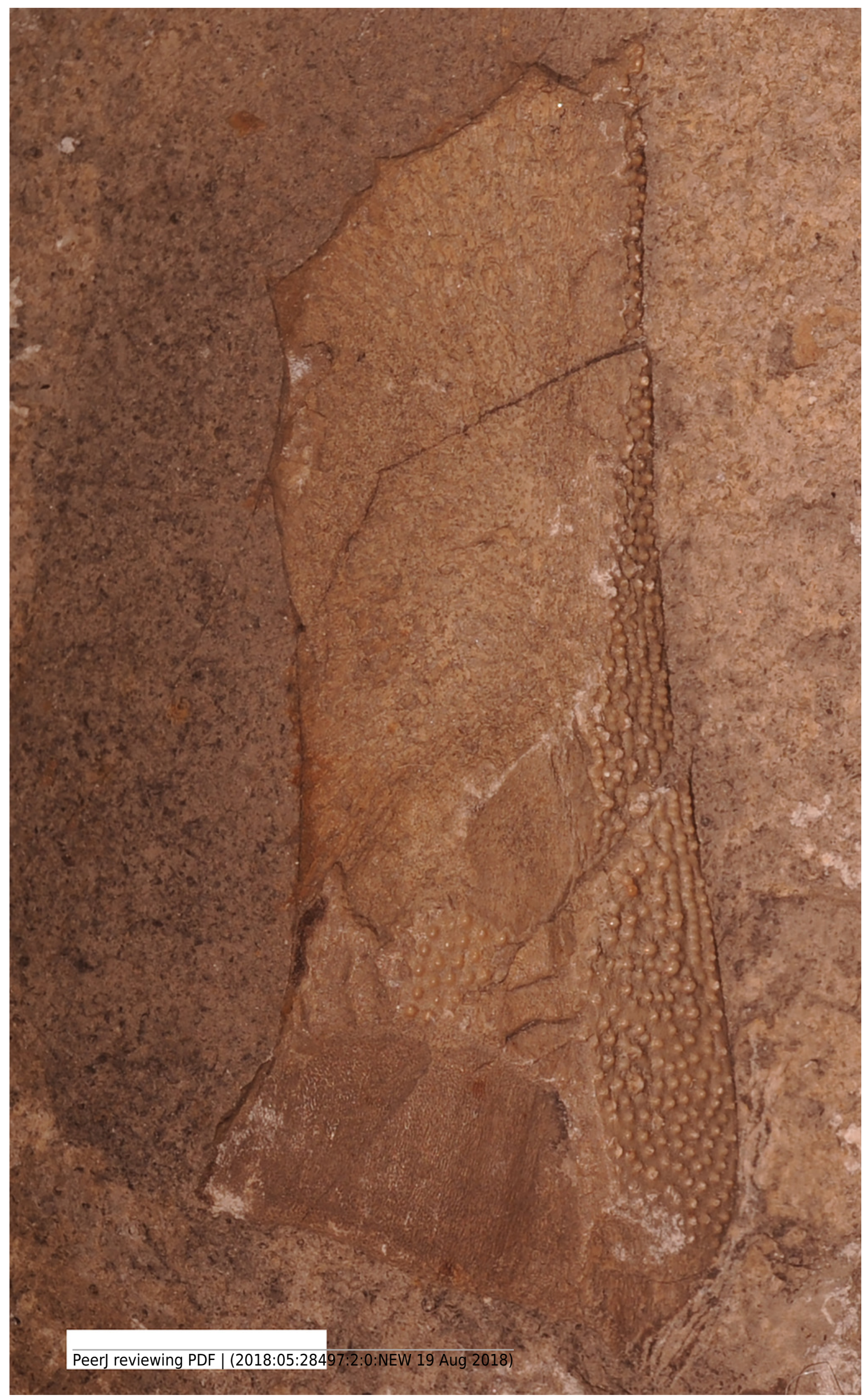




\section{Figure 10}

A supragnathal plate from an unknown ptyctodont from the Traverse Group.

Specimen recovered from an unknown locality referred to as "Locality 650 of the Winchell Survey", in Alpena, Alpena County, MI. UMMP 14374. Scale bar equals $1 \mathrm{~cm}$.

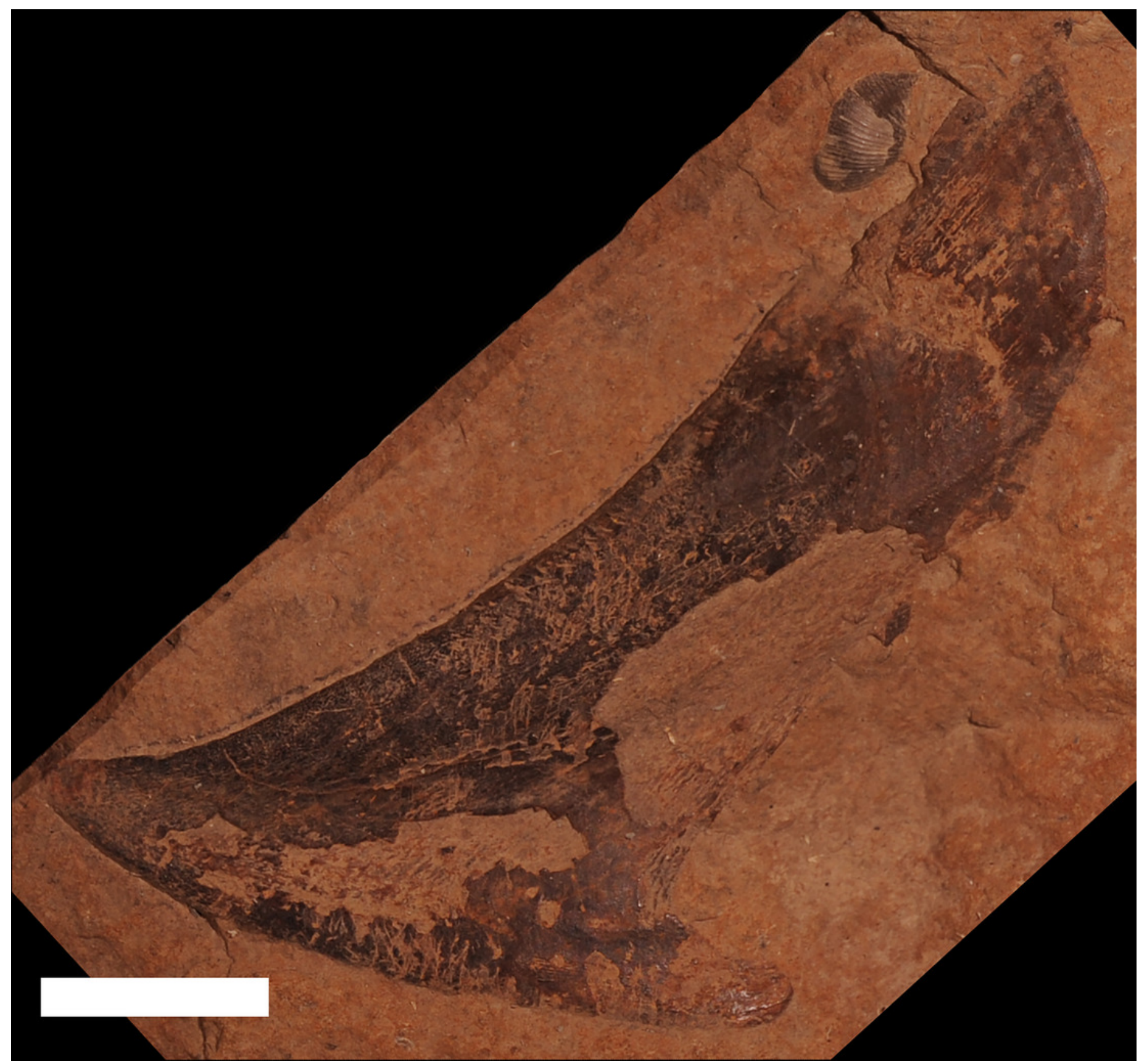




\section{Figure 11}

Specimens of the 'acanthodian' Machaeracanthus sp.

(A), a large spine from Machaeracanthus sp.,from the Dundee Limestone of London

Township, Monroe County, UMMP 3521. Scale bar equals $1 \mathrm{~cm}$. (B), a spine from

?Machaeracanthus sp.(originally identified as A.gracillimus), from the Rockport Quarry

Limestone at the abandoned Kelly Island Limestone Quarry at Rockport State Park, Alpena

County, UMMP 13047. Scale bar equals $1 \mathrm{~cm}$.
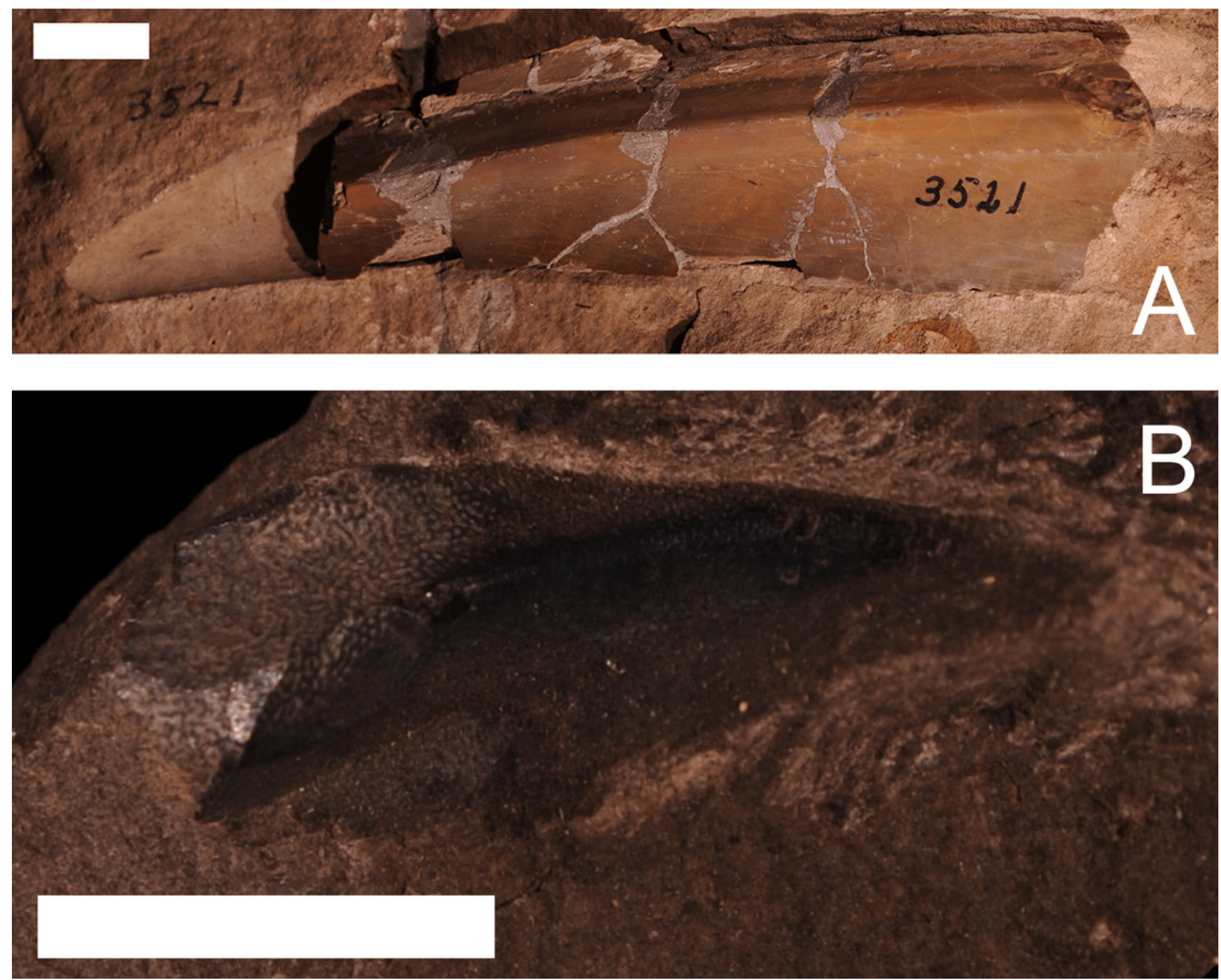


\section{Figure 12}

The skull of Chirodipterus onawayensis.

Specimen recovered from from the Newton Creek Limestone of Onaway Stone Quarry, north of Onaway, Presque Isle County. Specimen photo from Schultze (1982), Figure 2, modified and reprinted with permission of Taylor and Francis Ltd, http://www.tandfonline.com. This specimen is reported to be unnumbered at the Great Lakes Area Paleontological Museum, but is missing. Scale bar equals $1 \mathrm{~cm}$.

*Note: Auto Gamma Correction was used for the image. This only affects the reviewing manuscript. See original source image if needed for review.

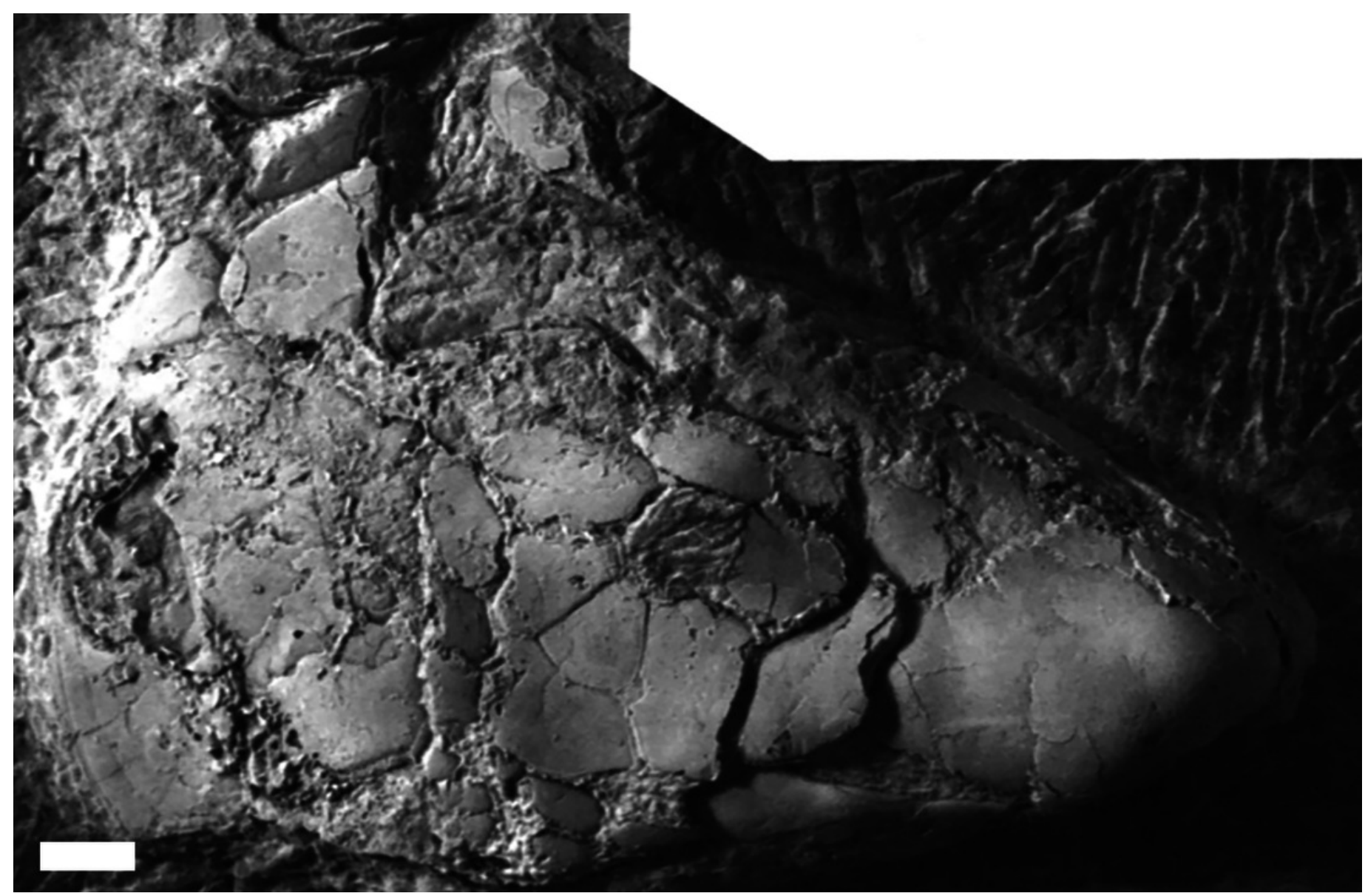




\section{Figure 13}

A representation of the Devonian vertebrate fauna known from Michigan.

Animals not to scale. Drawing by L.S. (A) The vertebrate fauna from the Middle Devonian of Michigan. (1) Acondylacanthus (Chondrichthyes); (2), Dinomylostoma (Arthrodira;

'Placodermi'); (3), Chirodipterus (Dipnoi; Sarcopterygii); (4), Dunkleosteus (Arthrodira; 'Placodermi'); (5), Onychodus (Onychodontida; Sarcopterygii); (6), Mylostoma (Arthrodira; 'Placodermi'); (7), Protitianichthys (Arthrodira; 'Placodermi'); (8), Oracanthus (Acanthodida; 'Acanthodii'); (9), Machaeracanthus (Ischnacanthida; 'Acanthodii'); (10), Gyracanthus (Gyracanthida; 'Acanthodii'); (11), Eczematolepis (Ptyctodontida; 'Placodermi'); (12), Holonema (Arthrodira; 'Placodermi'). (B) The vertebrate fauna from the Late Devonian of Michigan. (13) Aspidichthys (Arthrodira; 'Placodermi'); (14), Trachosteus (Arthrodira: 'Placodermi'); (15), Diplognathus (Arthrodira; 'Placodermi'); (16), Ptyctodontida indet. ('Placodermi'). 


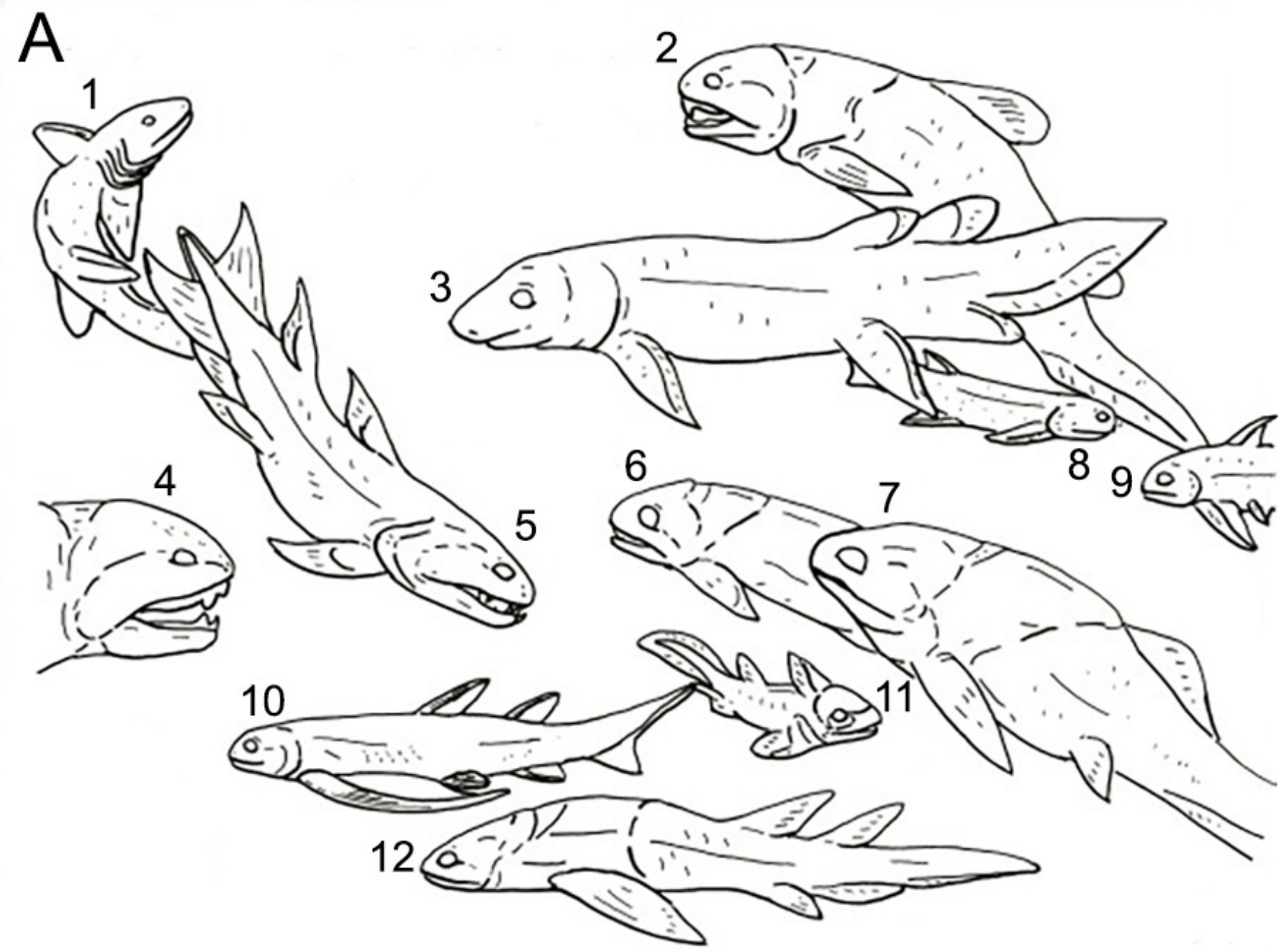

B

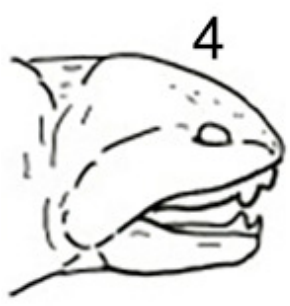

13

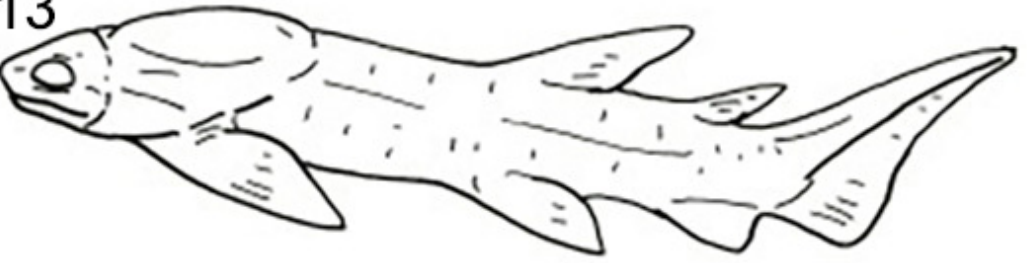

15
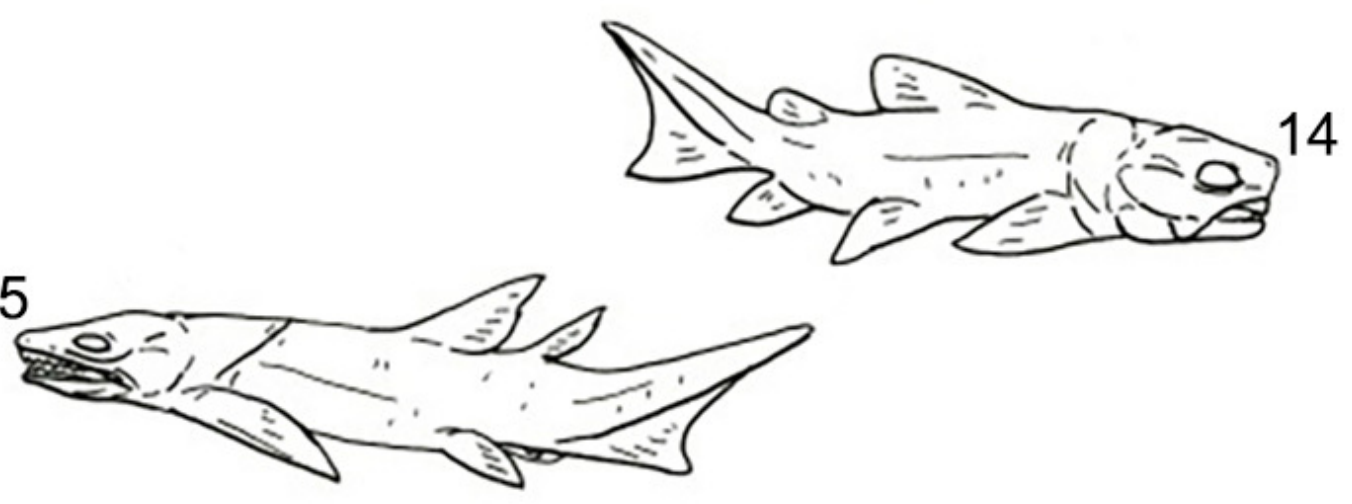

16 